\title{
A Company Improvement Analysis using the AHP/ANP Methods and the Modern Technology
}

\author{
Valerica NESTIAN ${ }^{\star}$, Silvia ISTRATE ${ }^{\star \star}$, Maria NEAGU ${ }^{\star \star \star}$
}

\begin{tabular}{l} 
A R T I C L E I N F O \\
\hline Article history: \\
Accepted January 2019 \\
Available online April 2019 \\
\hline JEL Classification \\
M10, M21 \\
Keywords: \\
AHP, ANP, SuperDecisions
\end{tabular}

AHP, ANP, SuperDecisions

\begin{abstract}
A B S T R A C T
This paper has as a goal the application of the modern technology (the "SuperDecisions" software) for the analysis of the factors that determine a company improvement and the determination of the priorities of the methods that the company management might consider in order to improve the company activity. Having as a point of start the analysis obtained using the AHP ("Analytic Hierarchy Process") and the ANP ("Analytic Network Process") methods through numerical methods, this work underlines the equality of the results provided by these two different ways of solving the problem and the way in which the modern technology changes the working environment for the AHP/ANP applications.
\end{abstract}

(C) 2019 EAI. All rights reserved.

\section{Introduction}

The modern technology and the commercial software available nowadays are offering to the user a way of solving the problems that is very close to an environment that is familiar to the young students, researchers, et al. SuperDecisions is one of this software programs. It translates the AHP ("Analytical Hierarchy Process") and the ANP ("Analytic Network Process") methods (Neagu, 2016, 2017) into a modern environment.

A great number of research works that are using the SuperDecisions software are encountered in the scientific literature, while their domains of study vary as follows:

* education (Aragoné-Beltrán, 2017; Gibney, 2007);

\# industry (Hasan et al, 2012; Akyildiz et al., 2014; Milani et al, 2013; Aljurais et al., 2016; Mu et al., 2016;

Önüt et al., 2008);

\# energy sector (Aragonés-Beltrán et al, 2014; Xu and Chan, 2013; Canemmit et al, 2014; Atmaca and Basar, 2012);

* transportation (Ivanovíc, 2013);

\# decision-making process (De Ambroggi and Trucco, 2011; Hallikainen et a;, 2009; Keramati and Salehi, 2013; Burnaz and Topcu, 2011).

This paper uses the analysis of Istrate et al. (2018) regarding a company activity improvement and translates it into the SuperDecisions environment. The results obtained show not only the equivalence of the two methods of solving the problem, but also the modern application of the AHP/ANP methods.

\section{The problem formulation}

\subsection{The problem decomposition}

An analysis realized by the leaders of a company (a company considered here as an example) underlines the objective of the study ("Company activity improvement"), the criteria ("Management", "Human Resources", "Acquisitions" and "IT") and the subcriteria as they are revealed by Table 1: "Acquisitions plan" and "Tenders", "Employment criteria" and "Personnel training", "Software" and "Software Usage", "Decisions" and "Tasks". Table 1 presents, also, the improvement methods that the analysis team considers as being appropriate for the company activity improvement: "Competence", "Economy", "Education", "Efficiency", "Evaluation", "Finance" and "Training". 
Table 1 . The criteria, the subcriteria and the methods of a company activity improvement.

\begin{tabular}{|c|c|c|c|c|}
\hline Objective & \multicolumn{4}{|c|}{ Company activity improvement } \\
\hline Criteria & Acquisitions & Human resources & IT & Management \\
\hline \multirow[t]{2}{*}{ Subcriteria } & Acquisitions plan & Employment criteria & Software & Decisions \\
\hline & Tenders & Personel training & Software usage & Tasks \\
\hline Methods & Competence Economy & \begin{tabular}{|l|l|} 
Education & Efficiency
\end{tabular} & valuation Finance & Training \\
\hline
\end{tabular}

If the "Objective" $\rightarrow$ "Criteria" $\rightarrow$ "Subcriteria" part of the analysis requires the application of the AHP method, the "Subcriteria" $\rightarrow$ "Methods" part requires the ANP method application due to the inner dependencies of the "Subcriteria" and the "Methods" components. The simultaneous application of the AHP and the ANP methods conducts us to an original application of the steps that these methods require (Neagu, 2016, 2017).

\subsection{The clusters and the nodes definition}

Figure 1 presents the clusters and the nodes of the SuperDecisions program that is developed here in order to solve the problem. There are three clusters: "Criteria", "Subcriteria" and "Methods". The cluster "Criteria" contains four nodes (a node for each criterion), the cluster "Subcriteria" contains eight nodes (a node for each subcriterion), while the cluster "Methods" contains seven nodes (a node for each method).

Figure 1. The clusters and the nodes of the SuperDecisions program for a company activity improvement

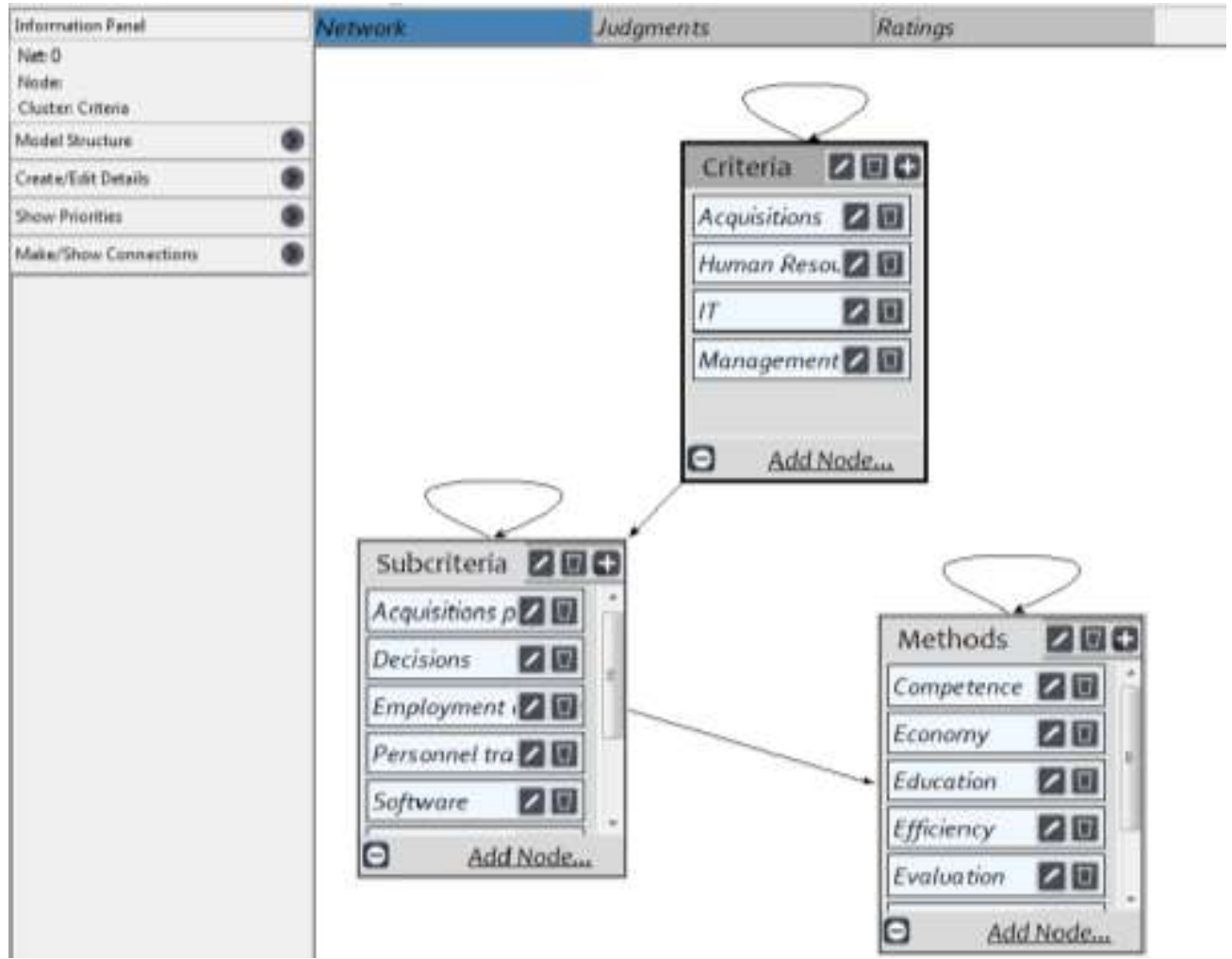

\subsection{The connections definitions}

Figure 2 shows the connections of the "Criteria" nodes: "Acquisition" (Figure 2a), "Human Resources" (Figure 2b), "IT" (Figure 2c) and "Management" (Figure 2d). 
Figure 2. The connections of the "Criteria" cluster nodes

a) "Acquisitions"

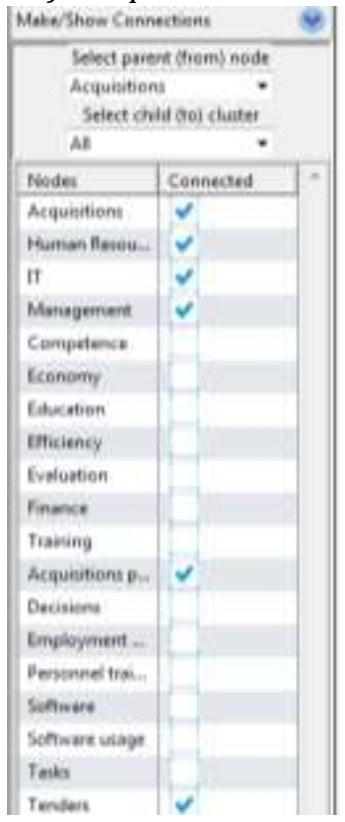

b) "Human Resources"

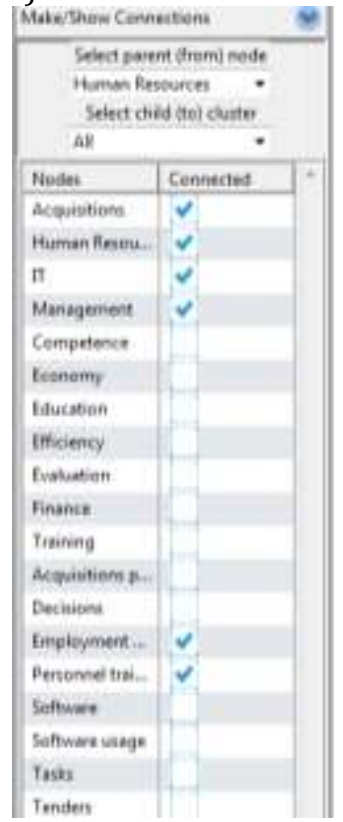

c) "IT"

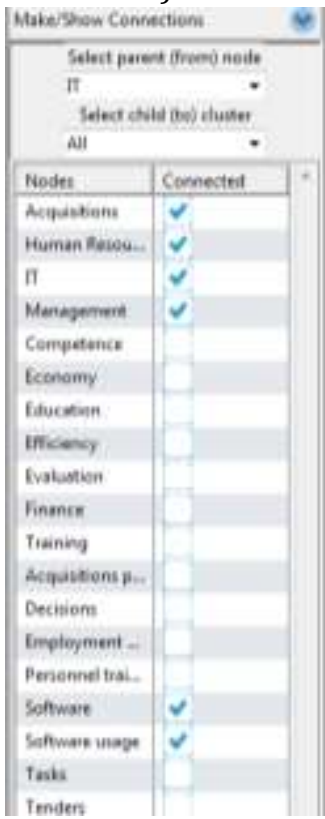

d) "Management"

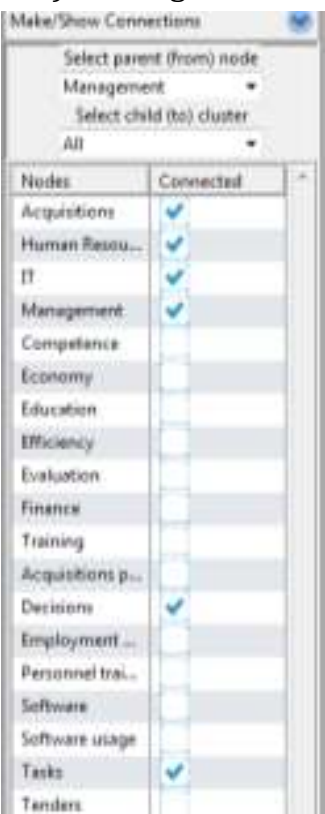

Successively, the connections in the "Subcriteria" cluster are defined by Figure 3 for the nodes: "Acquisitions plan" (Figure 3a), "Decisions" (Figure 3b), "Employment criteria" (Figure 3c), "Personnel training" (Figure 3d), "Software" (Figure 3e), "Software usage" (Figure 3f), "Task" (Figure 3g) and "Tenders" (Figure 3h).

Figure 3. The connections of the nodes in the "Subcriteria" cluster

a) "Acquisitions plan"

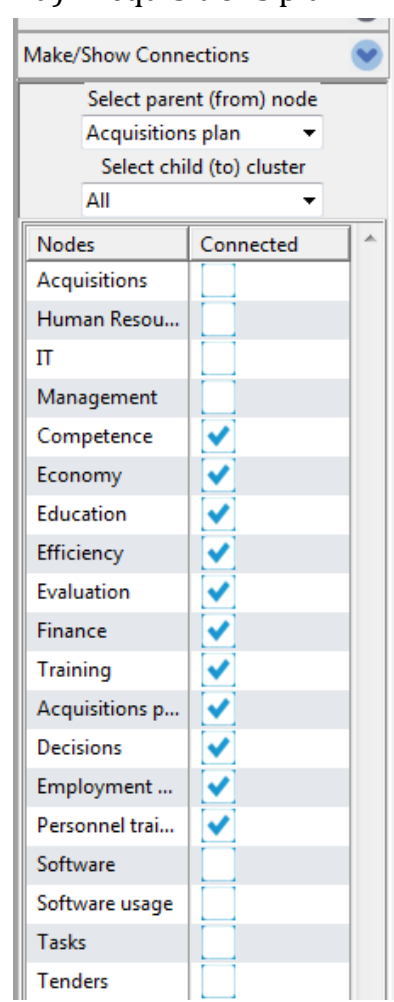

b) "Decisions"

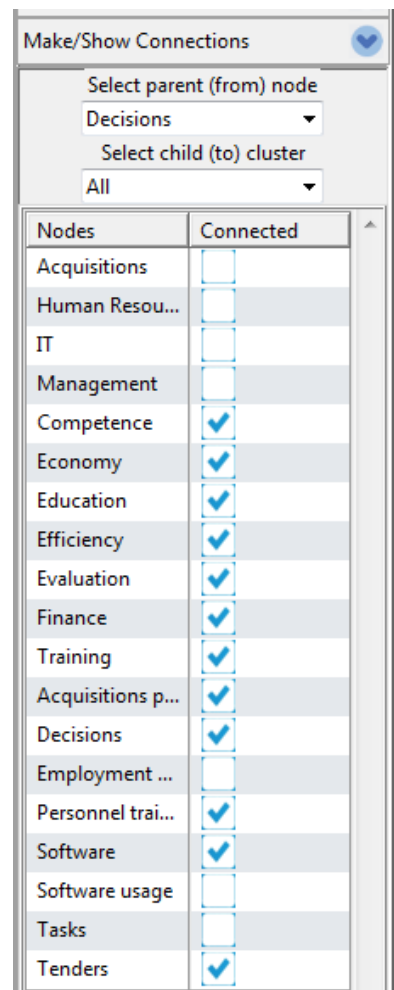

c) "Employment criteria"

\begin{tabular}{|c|c|c|c|}
\hline \multicolumn{3}{|c|}{ Make/Show Connections } & $\bullet$ \\
\hline \multicolumn{4}{|c|}{ Select parent (from) node } \\
\hline \multicolumn{4}{|c|}{ Employment criteria $\longrightarrow$} \\
\hline \multicolumn{4}{|c|}{ Select child (to) cluster } \\
\hline All & \multicolumn{3}{|c|}{$\checkmark$} \\
\hline Nodes & \multicolumn{2}{|c|}{ Connected } & 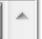 \\
\hline Acquisitions & & & \\
\hline Human Resou... & & & \\
\hline IT & & & \\
\hline Management & & & \\
\hline Competence & $\checkmark$ & & \\
\hline Economy & $\checkmark$ & & \\
\hline Education & $\checkmark$ & & \\
\hline Efficiency & $\checkmark$ & & \\
\hline Evaluation & $\checkmark$ & & \\
\hline Finance & $\checkmark$ & & \\
\hline Training & $\checkmark$ & & \\
\hline \multicolumn{2}{|l|}{ Acquisitions p... } & & \\
\hline Decisions & $\checkmark$ & & \\
\hline Employment ... & $\checkmark$ & & \\
\hline Personnel trai... & & & \\
\hline Software & & & \\
\hline Software usage & & & \\
\hline Tasks & $\checkmark$ & & \\
\hline Tenders & & & \\
\hline
\end{tabular}

d) "Personnel training"

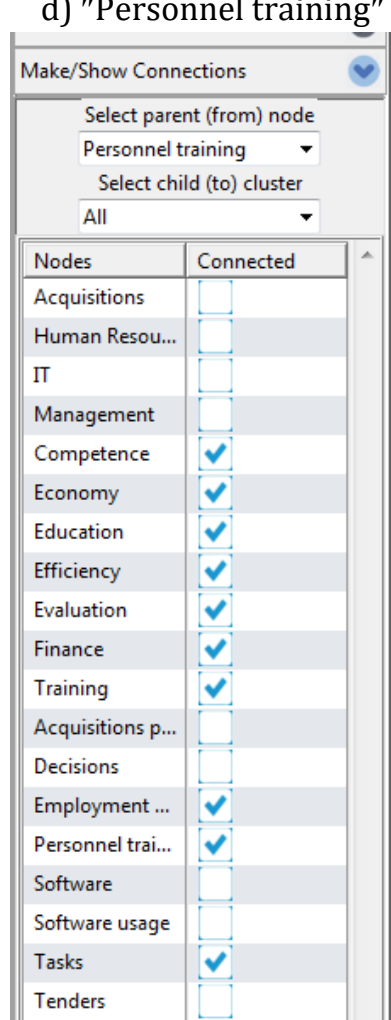


e) "Software"

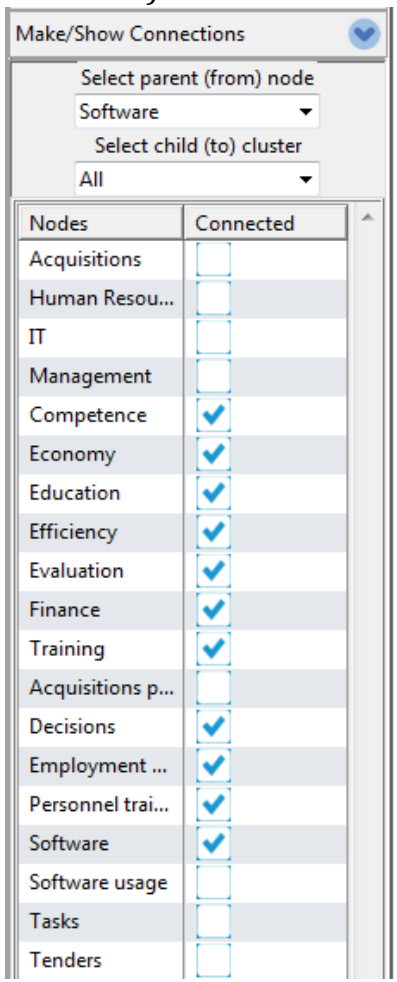

f) "Software usage"

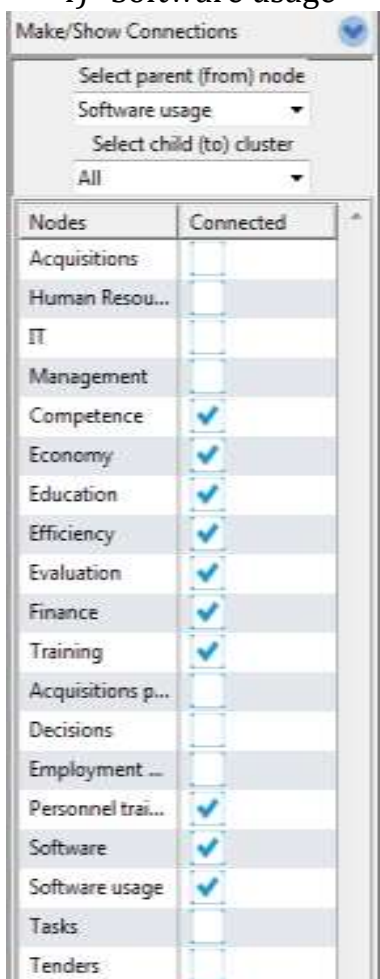

g) "Tasks"

\begin{tabular}{|l|}
\hline Make/Show Connections \\
\hline Select parent (from) node \\
\hline Tasks \\
\hline Select child (to) cluster \\
\hline All \\
\hline
\end{tabular}

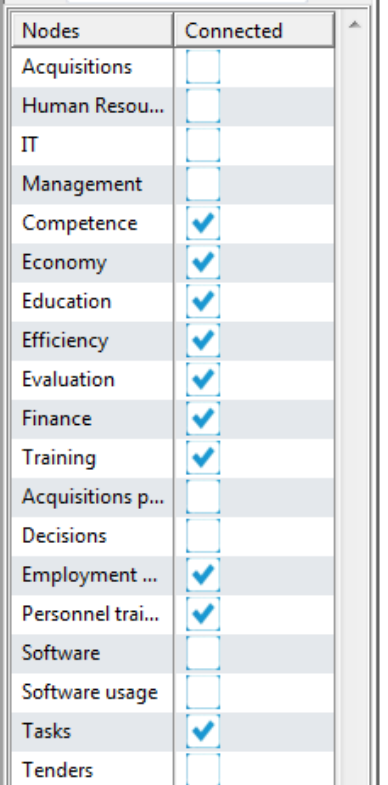

h) "Tenders"

\begin{tabular}{|c|c|c|}
\hline \multicolumn{2}{|c|}{ Make/Show Connections } & $\checkmark$ \\
\hline \multicolumn{3}{|c|}{ Select parent (from) node } \\
\hline & & \\
\hline \multicolumn{3}{|c|}{ Select child (to) cluster } \\
\hline All & \multicolumn{2}{|c|}{$*$} \\
\hline Nodes & Connected & \\
\hline Acquisitions & & \\
\hline Human Resou... & & \\
\hline$\pi$ & & \\
\hline Management & & \\
\hline Competence & $\checkmark$ & \\
\hline Economy & $\checkmark$ & \\
\hline Education & $\checkmark$ & \\
\hline Efficiency & $\checkmark$ & \\
\hline Evaluation & $\checkmark$ & \\
\hline Finance & $\checkmark$ & \\
\hline Training & $\checkmark$ & \\
\hline Acquisitions p... & $\checkmark$ & \\
\hline Decisions & $\checkmark$ & \\
\hline Employment - & & \\
\hline Personnel traí... & $\checkmark$ & \\
\hline Software & & \\
\hline Software usage & & \\
\hline Tasks & & \\
\hline Tenders & $\checkmark$ & \\
\hline
\end{tabular}

The nodes of the "Methods" cluster are inter-connected as Figure 4 reveals for the nodes "Competence" (Figure 4a), "Economy" (Figure 4b), "Education" (Figure 4c), "Efficiency" (Figure 4d), "Evaluation" (Figure 4e), "Finance" (Figure 4f) and "Training" (Figure 4g).

Figure 4. The connections of the nodes in the "Methods" cluster

a) "Competence"

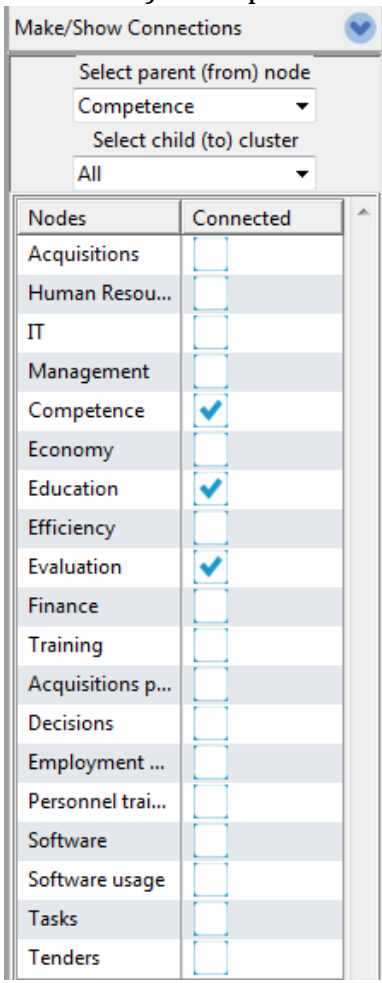

b) "Economy"

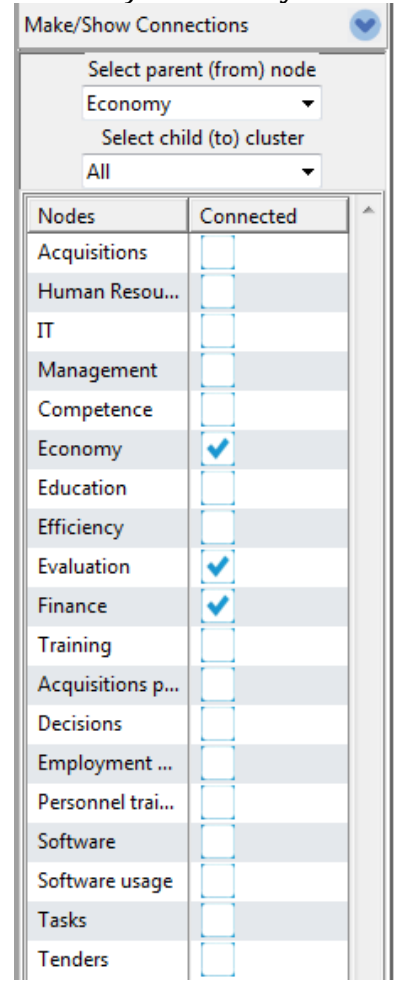

c) "Education"

\begin{tabular}{|c|c|c|}
\hline \multicolumn{2}{|c|}{ Make/Show Connections } & $\bullet$ \\
\hline \multicolumn{3}{|c|}{ Select parent (from) node } \\
\hline \multicolumn{2}{|l|}{ Education } & \\
\hline \multicolumn{3}{|c|}{ Select child (to) cluster } \\
\hline All & \multicolumn{2}{|c|}{. } \\
\hline Nodes & Connected & A \\
\hline \multicolumn{3}{|l|}{ Acquisitions } \\
\hline \multicolumn{3}{|l|}{ Human Resou... } \\
\hline \multicolumn{3}{|l|}{ IT } \\
\hline \multicolumn{3}{|l|}{ Management } \\
\hline \multicolumn{3}{|l|}{ Competence } \\
\hline Economy & $\boldsymbol{v}$ & \\
\hline Education & $\boldsymbol{v}$ & \\
\hline Efficiency & $\checkmark$ & \\
\hline Evaluation & $\checkmark$ & \\
\hline \multicolumn{3}{|l|}{ Finance } \\
\hline \multicolumn{3}{|l|}{ Training } \\
\hline \multicolumn{3}{|l|}{ Acquisitions p... } \\
\hline \multicolumn{3}{|l|}{ Decisions } \\
\hline \multicolumn{3}{|l|}{ Employment ... } \\
\hline \multicolumn{3}{|l|}{ Personnel trai... } \\
\hline \multicolumn{3}{|l|}{ Software } \\
\hline \multicolumn{3}{|l|}{ Software usage } \\
\hline \multicolumn{3}{|l|}{ Tasks } \\
\hline Tenders & & \\
\hline
\end{tabular}

d) "Efficiency"

\begin{tabular}{|c|c|c|}
\hline \multicolumn{2}{|c|}{ Make/Show Connections } & $\bullet$ \\
\hline \multicolumn{3}{|c|}{ Select parent (from) node } \\
\hline \multicolumn{2}{|l|}{ Efficiency } & \\
\hline \multicolumn{3}{|c|}{ Select child (to) cluster } \\
\hline All & \multicolumn{2}{|c|}{$\checkmark$} \\
\hline Nodes & Connected & 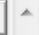 \\
\hline Acquisitions & & \\
\hline Human Resou... & & \\
\hline пा & & \\
\hline Management & & \\
\hline Competence & & \\
\hline Economy & & \\
\hline Education & $\checkmark$ & \\
\hline Efficiency & $\checkmark$ & \\
\hline Evaluation & $\checkmark$ & \\
\hline Finance & & \\
\hline Training & & \\
\hline Acquisitions $\mathrm{p} . .$. & & \\
\hline Decisions & & \\
\hline Employment ... & & \\
\hline Personnel trai... & & \\
\hline Software & & \\
\hline Software usage & & \\
\hline Tasks & & \\
\hline Tenders & & \\
\hline
\end{tabular}


e) "Evaluation"

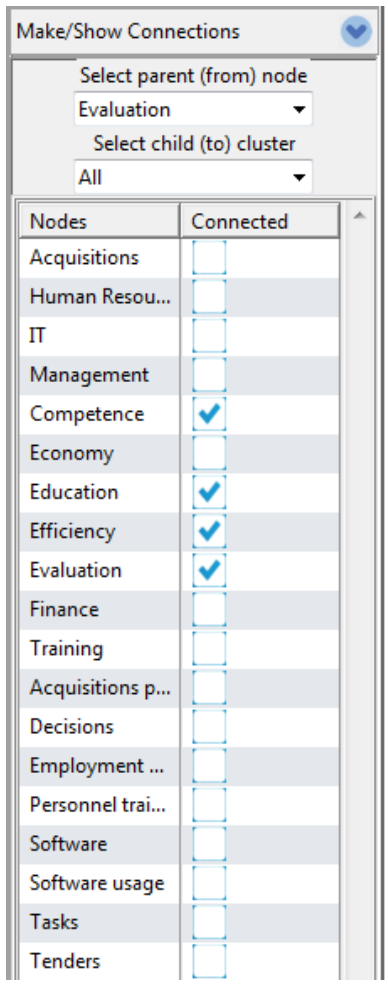

f) "Finance"

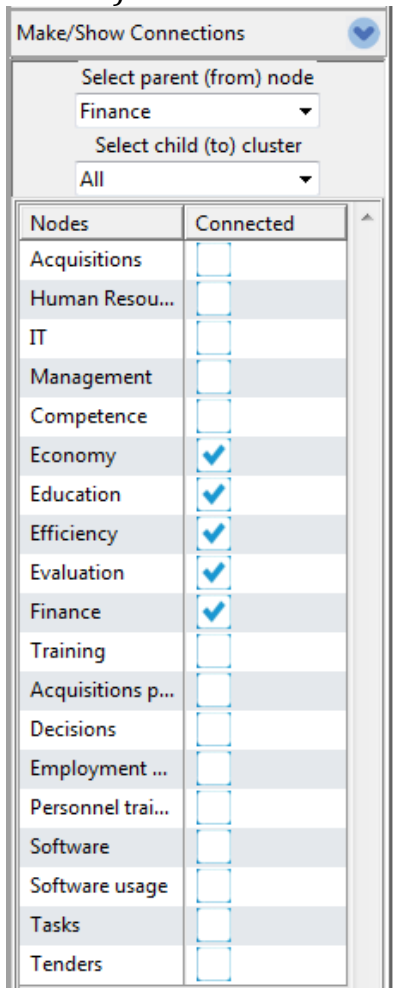

g) "Training"

\begin{tabular}{||l|l|}
\hline Make/Show Connections \\
\hline \multicolumn{2}{|c|}{ Select parent (from) node } \\
\hline Training \\
\hline \multicolumn{2}{|c|}{ Select child (to) cluster } \\
\hline Nodes \\
\hline Acquisitions \\
\hline Human Resou... \\
\hline IT \\
\hline Management \\
\hline Competence \\
\hline Economy \\
\hline Education \\
\hline Efficiency \\
\hline Evaluation \\
\hline Finance \\
\hline Training \\
\hline Acquisitions p... \\
\hline Decisions \\
\hline Employment ... \\
\hline Personnel trai... \\
\hline Software \\
\hline Software usage \\
\hline Tasks \\
\hline Tenders \\
\hline
\end{tabular}

\section{The matrices of comparison constructions}

After the connections are defined, we build the matrices of comparison, in the "Judgments" section of the software window, by choosing carefully in the left side (the "1. Choose" section) the node and the cluster.

Having in view the particularities of this problem, the six steps of the ANP method (Neagu, 2017) will guide further the process.

Step 1. The identification of the subcriteria and the methods. They have already been presented.

Step 2. The weights of the subcriteria. Here, we choose the node "Acquisitions" and the cluster "Criteria" and we answer the questionnaire in the central section of the window (see Figure 5) according to Table 2.

Table 2. The matrix of comparison and the weights of the criteria (Istrate et al., 2018)

\begin{tabular}{|l|c|c|c|c|c|}
\hline & Acquisitions & Human resources & IT & Management & Weight \\
\hline Acquisitions & 1 & 5 & 1 & 7 & 0.4407 \\
\hline Human resources & $1 / 5$ & 1 & $1 / 5$ & 3 & 0.1167 \\
\hline IT & 1 & 5 & 1 & 3 & 0.3693 \\
\hline Management & $1 / 7$ & $1 / 3$ & $1 / 3$ & 1 & 0.0733 \\
\hline
\end{tabular}

Figure 5. The numerical comparison of the criteria

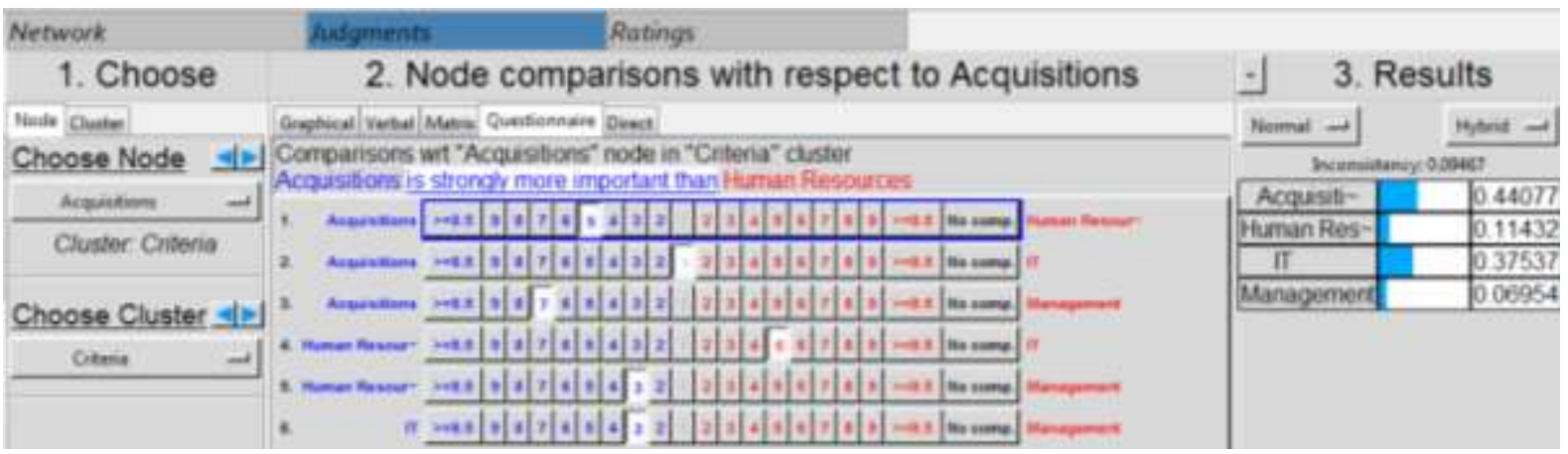


In the "3. Results" section, in the right side of the window, we notice that the criteria weights are the same as the values obtained in the Table 2 Similarly, keeping the same cluster, but changing successively the node: "Human resources", "IT" and "Management", we establish the inner dependence of all the nodes in the "Criteria" cluster.

The inconsistency of the answers is mentioned above the weights table allowing us to see instantly its value and to check that it is smaller than $10 \%$ as the AHP/ANP methods require.

The inner dependencies of the subcriteria are determined by choosing successively the nodes "Acquisitions" (Figure 6a), "Human resources" (Figure 6b), "IT" (Figure 6c) and "Management" (Figure 6d) and the cluster "Subcriteria". In the right window, the local weights reproduce the results of Tables $4 \div 8$ of Istrate et al. (2018).

Figure 6. The numerical comparison of the subcriteria for the criteria nodes.

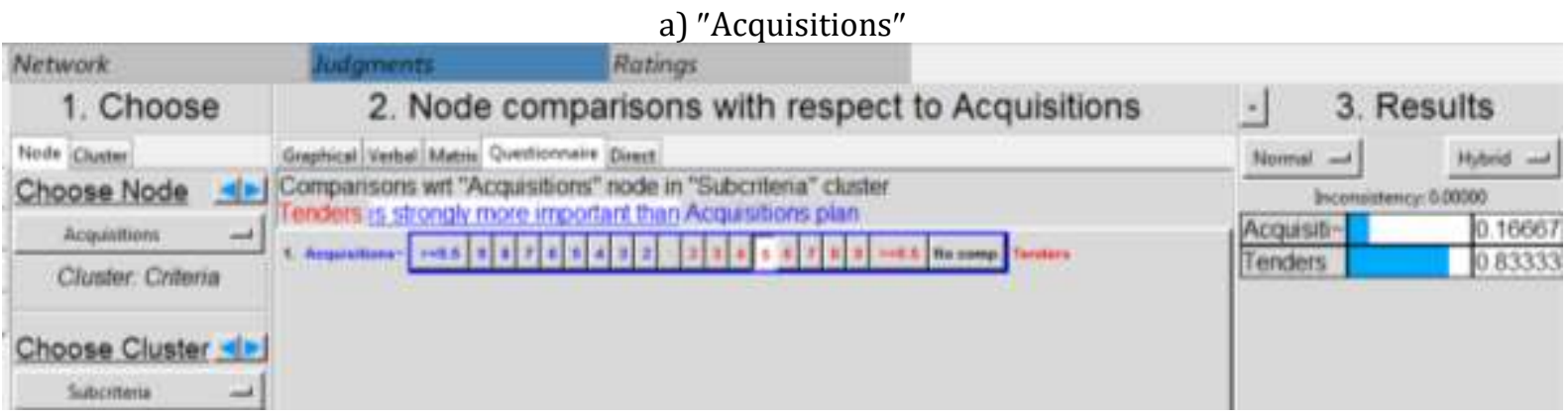

b) "Human Resources"

\begin{tabular}{|c|c|c|c|}
\hline Network & fudgments & & \\
\hline 1. Choose & 2. Node comparisons with respect to Human Resources & \multicolumn{2}{|c|}{ 3. Results } \\
\hline Node Chatut & Graphical Vebal / Matia Questionnaive Dind & Nermat -1 & Hytrid -1 \\
\hline Choose Node 4 & Compansons wit "Human Resourcess" node in "Sibcritera" cluster & \multicolumn{2}{|c|}{ Incomintenge 000000} \\
\hline Human Reseutes -1 & \multirow{4}{*}{ 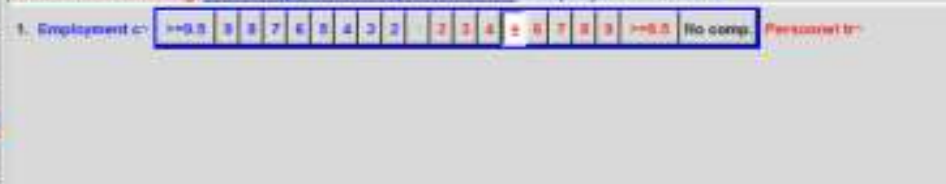 } & Employmen- & 0.16667 \\
\hline Ciuster Cntera & & Personnel- & 0.83333 \\
\hline Choose Cluster $\leq|y|$ & & & \\
\hline Suboterie & & & \\
\hline
\end{tabular}

c) "IT"

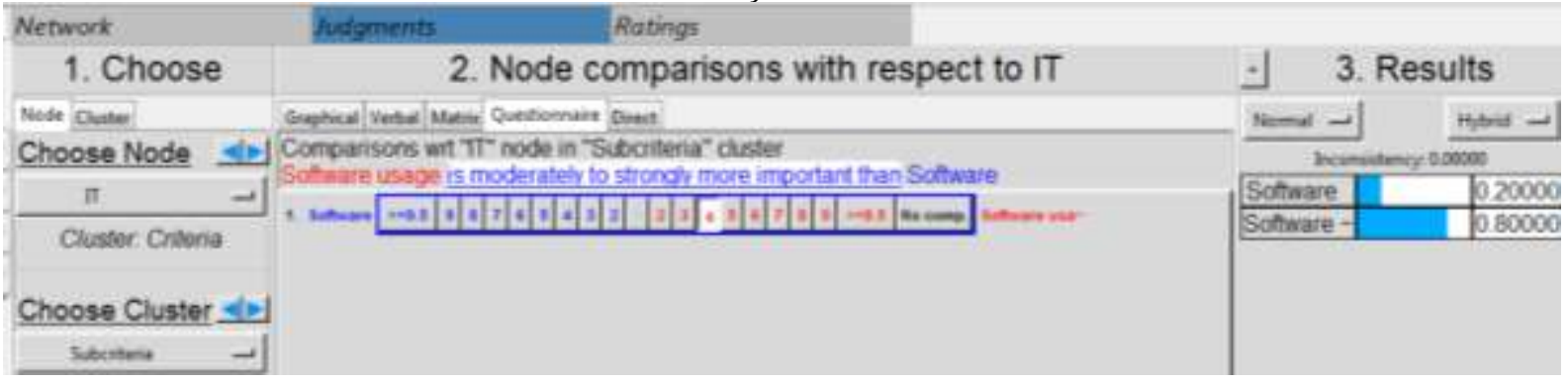

Figure 6. The numerical comparison of the subcriteria for the criteria nodes. d) "Management"

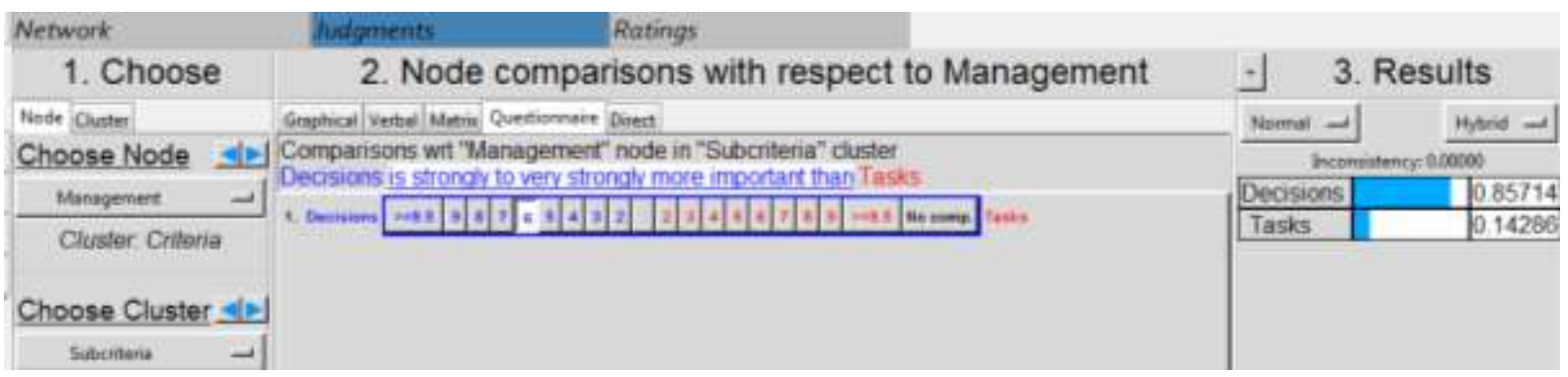

\section{Step 3. The weights of the methods for each subcriterion}

For each subcriterion, Figure 7 presents the questionnaire that compares the methods. For the nodes "Acquisitions plan" (Figure 7a), "Decisions" (Figure 7b), "Employment criteria" (Figure 7c), "Personnel 
training" (Figure 7d), "Software" (Figure 7e), "Software usage" (Figure 7f), "Tasks" (Figure 7g) and "Tenders" (Figure $7 \mathrm{~h}$ ), the methods priorities are determined using the Tables $12 \div 19$ of Istrate et al. (2018). As an example, Table 3 is translated using the SuperDecision software and it takes the form of Figure 7a.

Table 3. The measures comparison matrix for the "Acquisitions plan" subcriterion (Istrate et al., 2018)

\begin{tabular}{|c|c|c|c|c|c|c|c|c|}
\hline Measures & 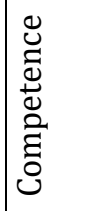 & 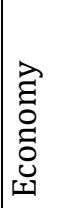 & 兽 & 总 & 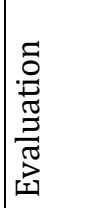 & 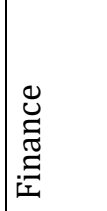 & 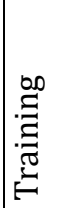 & $\begin{array}{l}\frac{\pi}{\frac{1}{00}} \\
\cdot \overline{0} \\
3\end{array}$ \\
\hline Competence & 1 & 3 & $1 / 2$ & 3 & 5 & $1 / 2$ & 1 & 0.1737 \\
\hline Economy & $1 / 3$ & 1 & $1 / 3$ & $1 / 2$ & $1 / 3$ & $1 / 3$ & 1 & 0.0633 \\
\hline Education & 2 & 3 & 1 & 3 & 2 & $1 / 2$ & 2 & 0.1953 \\
\hline Efficiency & $1 / 3$ & 2 & $1 / 6$ & 1 & $1 / 2$ & $1 / 6$ & 1 & 0.0708 \\
\hline Evaluation & $1 / 5$ & 3 & $1 / 5$ & 2 & 1 & $1 / 5$ & 1 & 0.0965 \\
\hline Finance & 2 & 3 & 2 & 6 & 5 & 1 & 2 & 0.3002 \\
\hline Training & 1 & 1 & $1 / 2$ & 1 & 1 & $1 / 2$ & 1 & 0.1000 \\
\hline
\end{tabular}

Figure 7. The numerical comparison of the methods for each subcriterion.

a) "Acquisition plan"

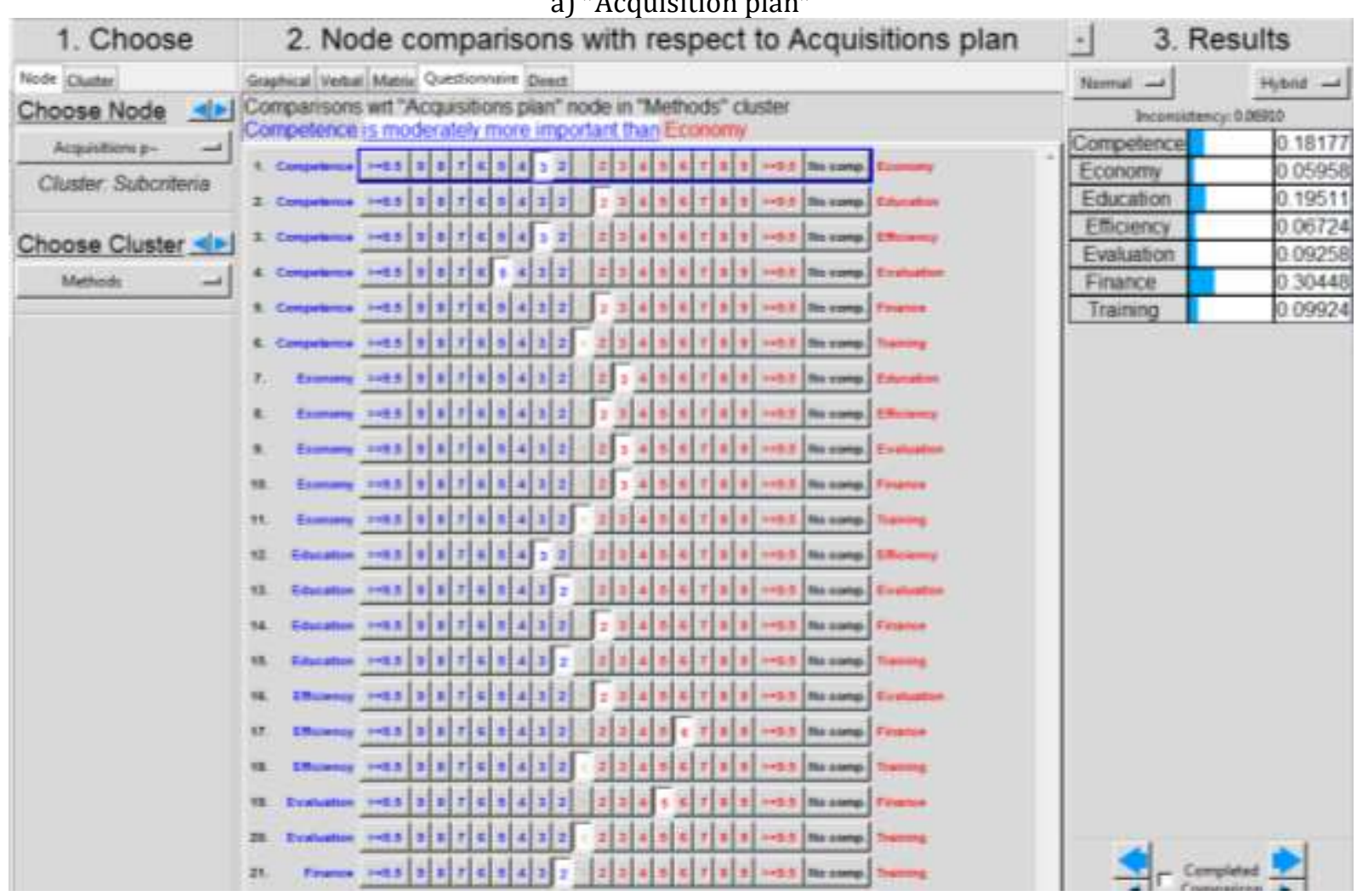


Figure 7. The numerical comparison of the methods for each subcriterion. (continued)

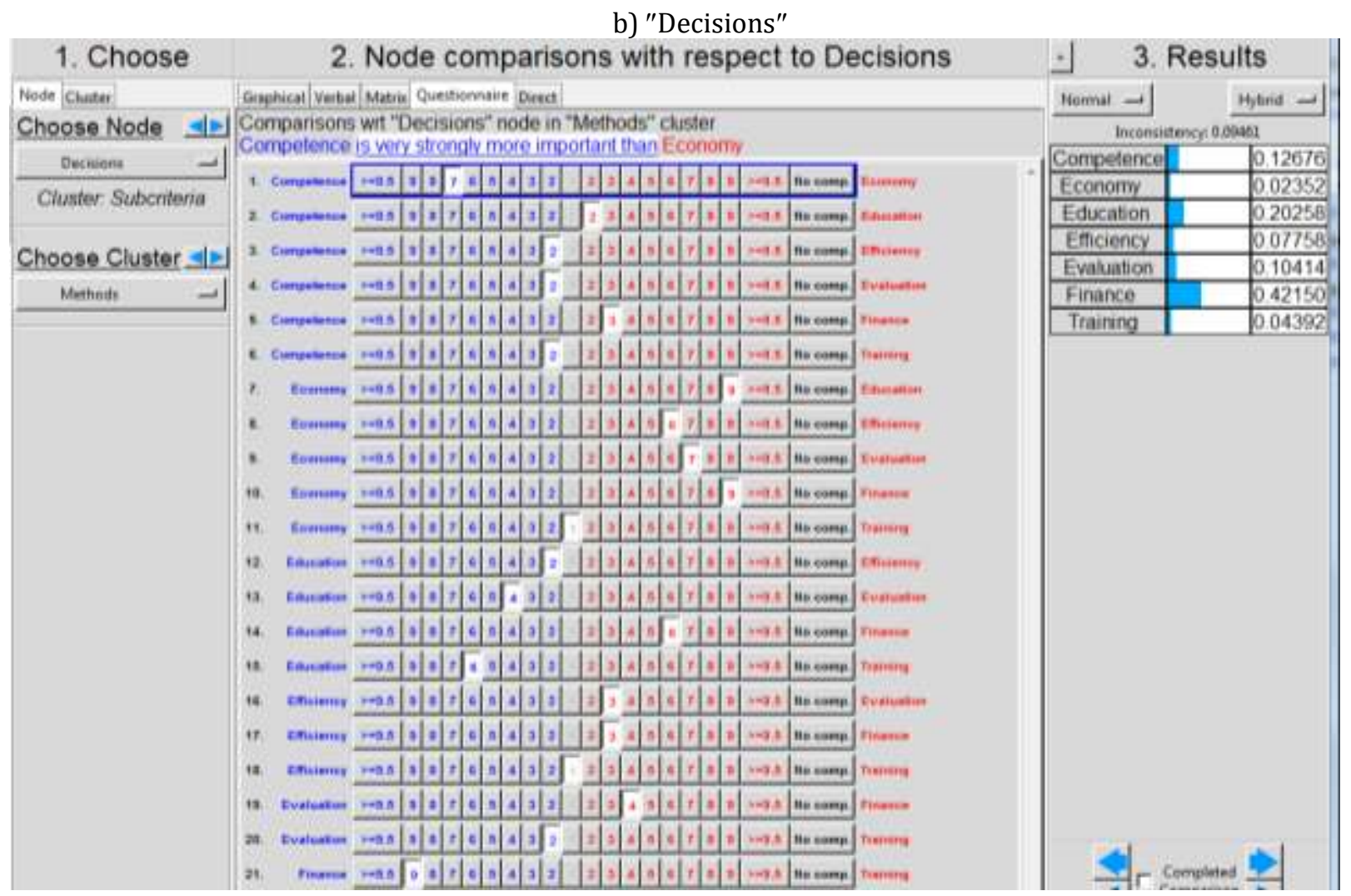

c) "Employment criteria"

\begin{tabular}{|c|c|c|c|c|c|}
\hline \multirow{3}{*}{ 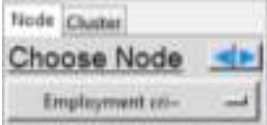 } & \multicolumn{3}{|c|}{ 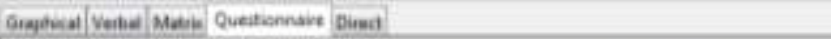 } & Thamei -1 & \multirow{2}{*}{ Bonid - } \\
\hline & Compansons: & s wit "Employment citena" node in "Mothods" cluste & & 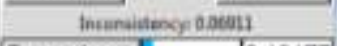 & \\
\hline & & & & Corroetence & 0.10177 \\
\hline Cluster Subcnteria & 1 consument & 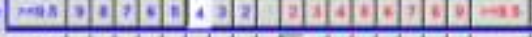 & Het $=4$ & Economy & 0.02889 \\
\hline & 2 ceapermet & 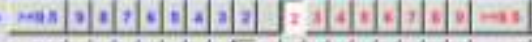 & 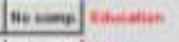 & Education & 0.16591 \\
\hline Choose Cluster $\leq$ ib & a conpermes & 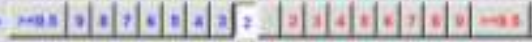 & 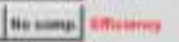 & Elliciency & 0.06215 \\
\hline Methodi -1 & 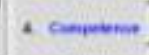 & 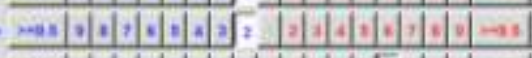 & 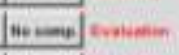 & \begin{tabular}{|l|} 
Evakiation \\
Finance
\end{tabular} & $\frac{0.08906}{0.51152}$ \\
\hline & s compers & 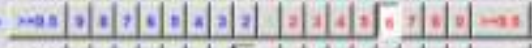 & nex-y & Training & 0.04070 \\
\hline & i compers & 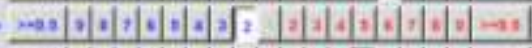 & 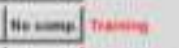 & & \\
\hline & , stonem & 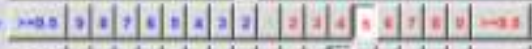 & ne-0y thenen & & \\
\hline & . Starrm & 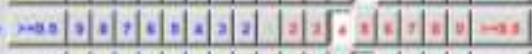 & 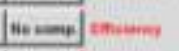 & & \\
\hline & 2 Esanum & 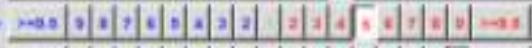 & Hever enotianion & & \\
\hline & "E sumem & 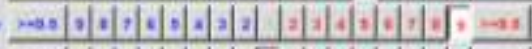 & 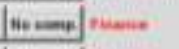 & & \\
\hline & "1 sunum & 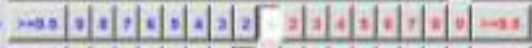 & 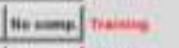 & & \\
\hline & 12 stanotion & 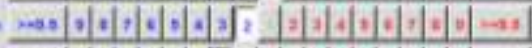 & 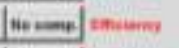 & & \\
\hline & 12 entuater & 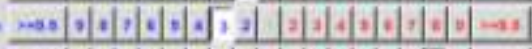 & nevent Snotianis & & \\
\hline & A Etheation & 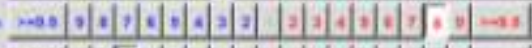 & 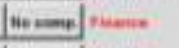 & & \\
\hline & is Eilusatis & 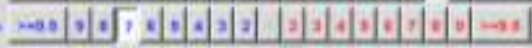 & 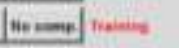 & & \\
\hline & 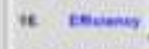 & 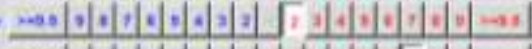 & 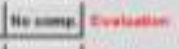 & & \\
\hline & "r. envereses & 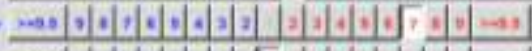 & Henentrumen. & & \\
\hline & 4 encienes & 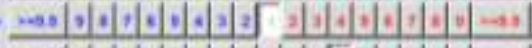 & 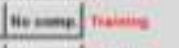 & & \\
\hline & As Evetuation. & 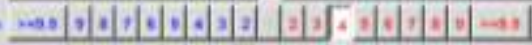 & 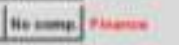 & & \\
\hline & it tvenato & 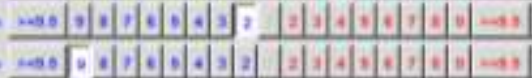 & 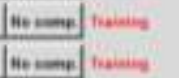 & $\leq$ & 4 \\
\hline
\end{tabular}


Figure 7. The numerical comparison of the methods for each subcriterion. (continued)

d) "Personnel training"

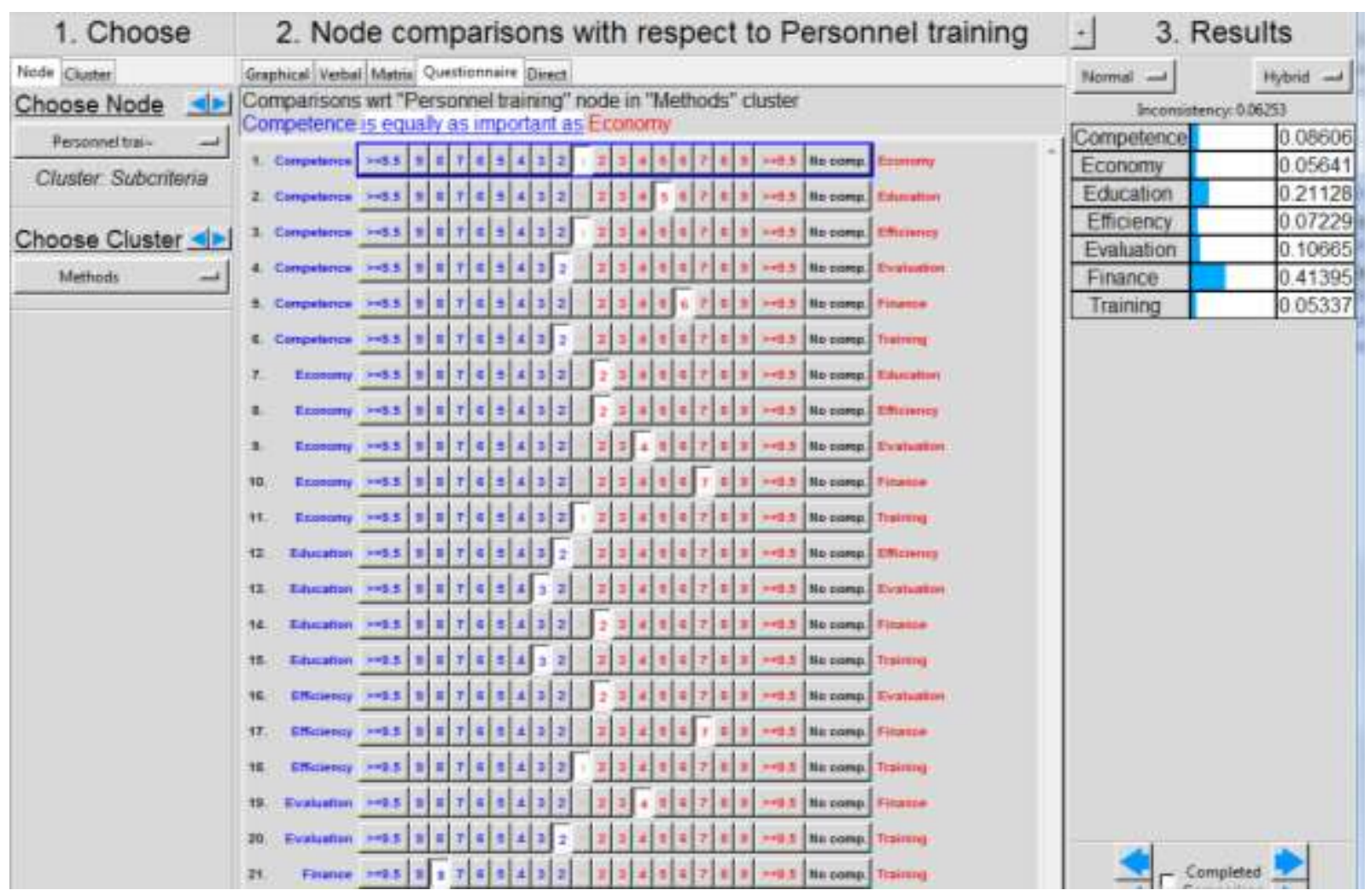

e) "Software"

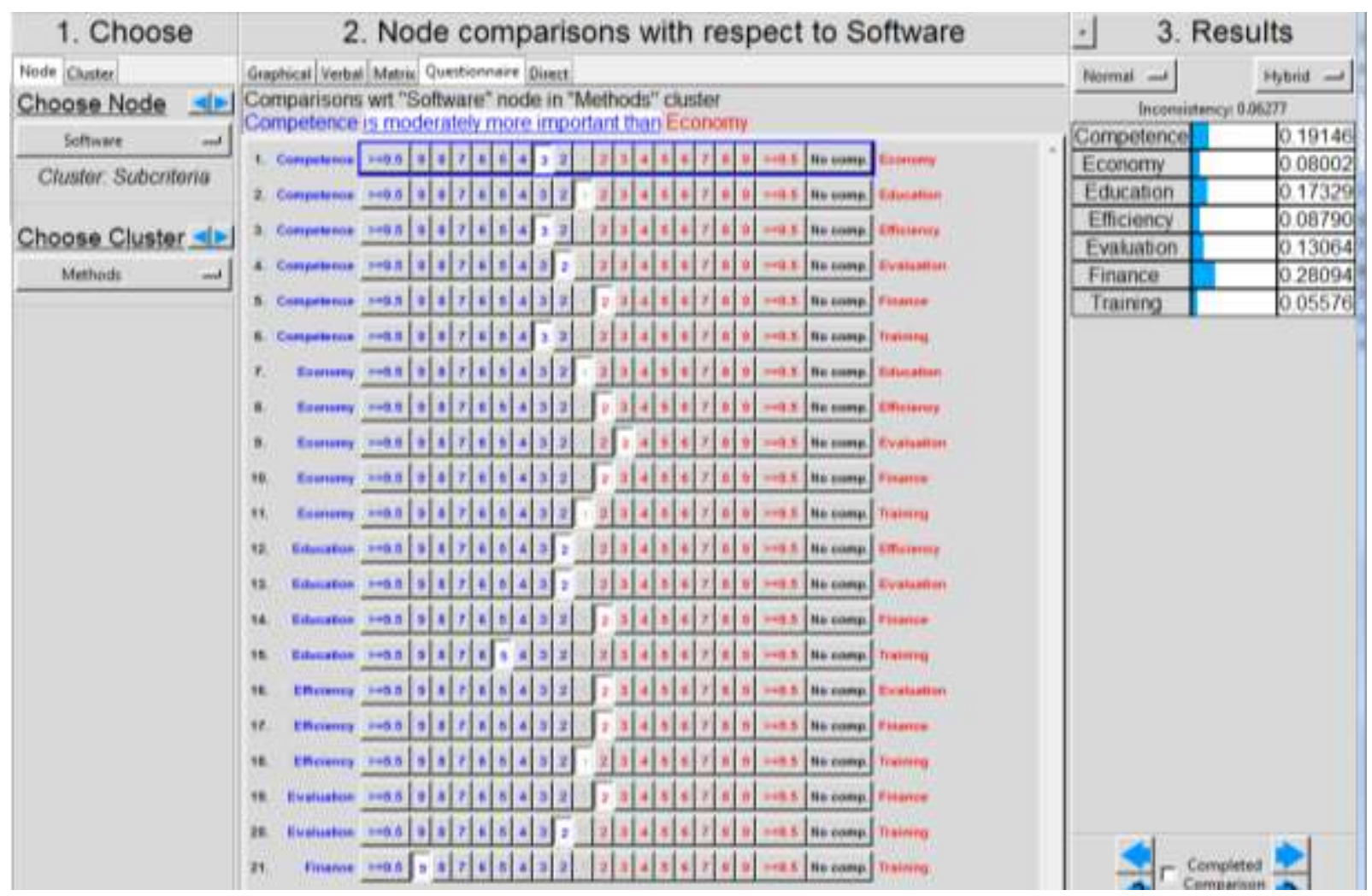


Figure 7. The numerical comparison of the methods for each subcriterion. (continued)

f) "Software usage"

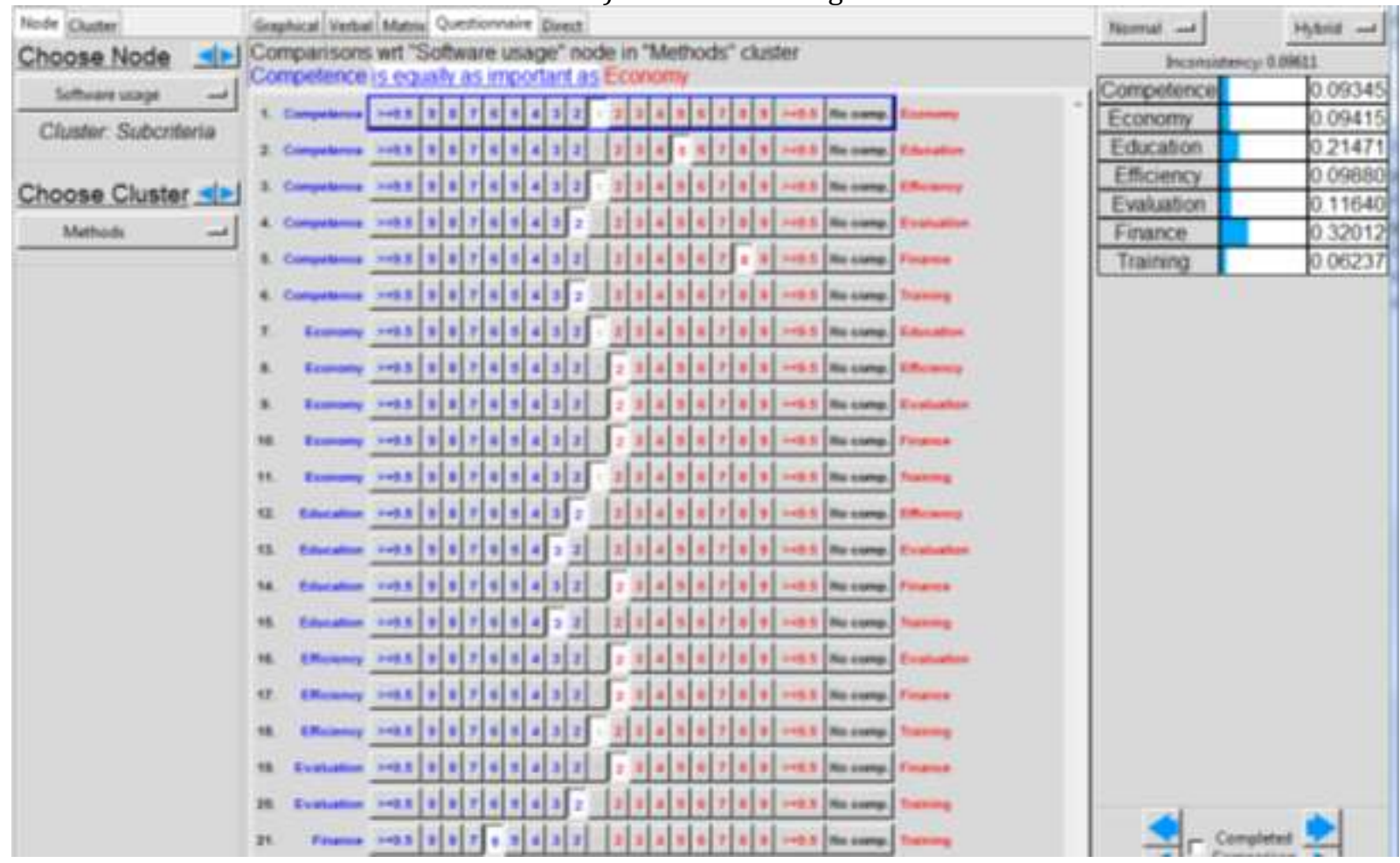

g) "Tasks"

\begin{tabular}{|c|c|c|c|c|}
\hline \multirow{2}{*}{$\begin{array}{l}\text { 1. Choose } \\
\text { Ninde Cunter }\end{array}$} & \multicolumn{2}{|l|}{ 2. Node compar } & \multicolumn{2}{|c|}{ 3. Results } \\
\hline & \multirow{3}{*}{\multicolumn{2}{|c|}{ 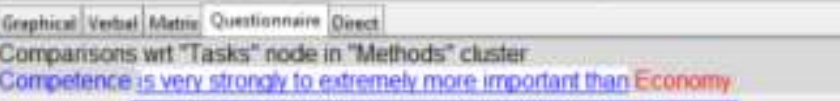 }} & Nemen -1 & isorid -1 \\
\hline Choose Node $I t$ & & & \multicolumn{2}{|c|}{ heomiteney 0.09613} \\
\hline & & & Competence & 0.16336 \\
\hline Cluster: Subcriteria & 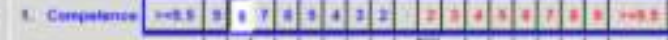 & 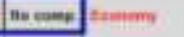 & Economy & 002867 \\
\hline 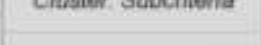 & 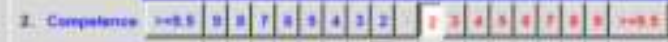 & 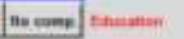 & Education & 0.23056 \\
\hline Choose Cluster $\leq \mid z$ & 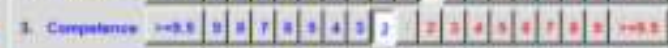 & 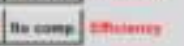 & Eticiency & 0.06895 \\
\hline Methode -1 & 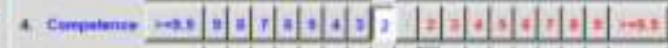 & Inecoms rrotuatm & \begin{tabular}{|l} 
Evaluation \\
Finance
\end{tabular} & $\frac{0.08566}{0.35112}$ \\
\hline & 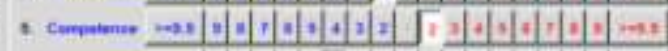 & 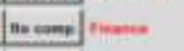 & \begin{tabular}{|l} 
Training \\
\end{tabular} & 006160 \\
\hline & 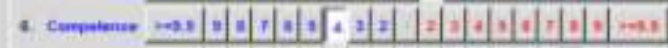 & 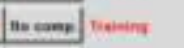 & & \\
\hline & 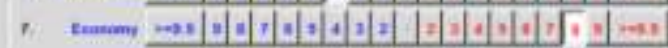 & 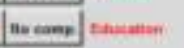 & & \\
\hline & 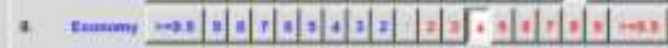 & 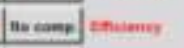 & & \\
\hline & 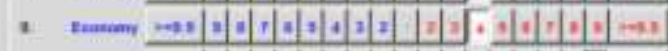 & nocons rututum & & \\
\hline & 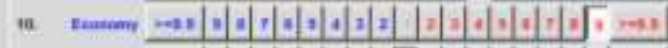 & 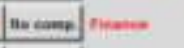 & & \\
\hline & 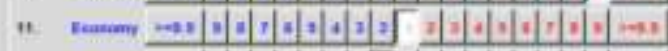 & 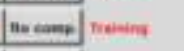 & & \\
\hline & 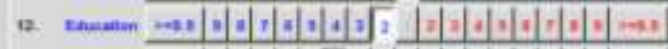 & 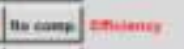 & & \\
\hline & 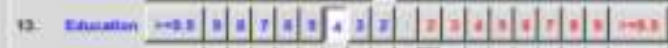 & 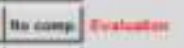 & & \\
\hline & 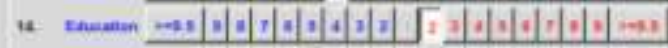 & 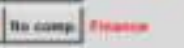 & & \\
\hline & 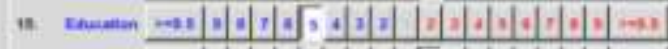 & nosent nowim & & \\
\hline & 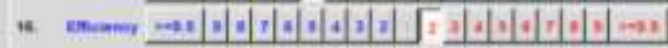 & necons notientm & & \\
\hline & 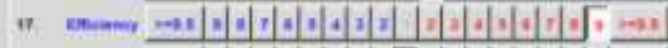 & 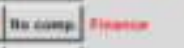 & & \\
\hline & 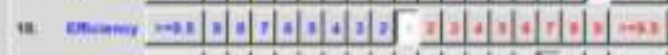 & nowan nowim & & \\
\hline & 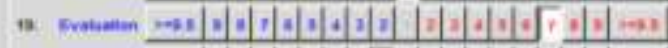 & 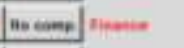 & & \\
\hline & $\begin{array}{l}\text { no Notumen } \\
n\end{array}$ & 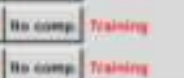 & & $\Rightarrow$ \\
\hline
\end{tabular}


Figure 7. The numerical comparison of the methods for each subcriterion. (continued)

h) "Tenders"

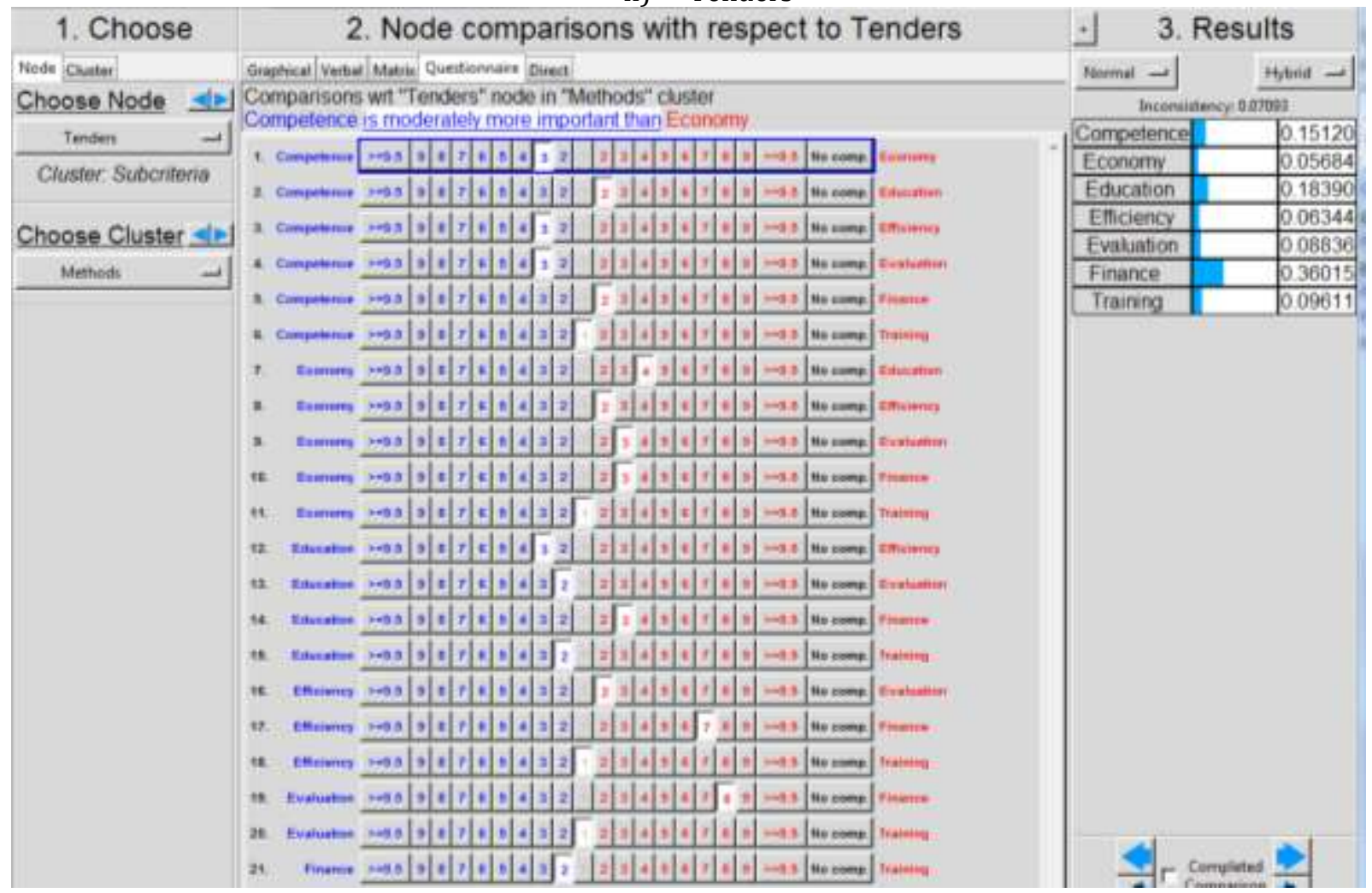

\section{Step 4. The inner dependencies of the subcriteria}

It is established by choosing successively the subcriteria and answering the questionnaires corresponding to each of them according to the tables $20 \div 27$ (Istrate et al. 2018) and Figure 3. These procedures are presented by Figure 8 for the subcriteria: "Acquisitions plan" (Figure 8a), "Decisions" (Figure 8b), "Employment criteria" (Figure 8c), "Personnel training" (Figure 8d), "Software" (Figure 8e), "Software usage" (Figure 8f), "Tasks" (Figure 8g) and "Tenders" (Figure 8h).

Figure 8. The inner dependencies of the subcriteria.

a) "Acquisitions plan"

\begin{tabular}{|c|c|c|c|}
\hline 1. Choose & 2. Node comparisons with respect to Acquisitions plan & \multicolumn{2}{|c|}{ 3. Results } \\
\hline Node Ghustr. & 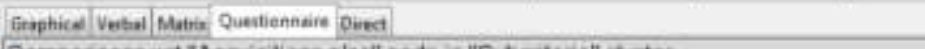 & Nomat -1 & Howd -1 \\
\hline Choose Node $\Delta \leq 1$ & 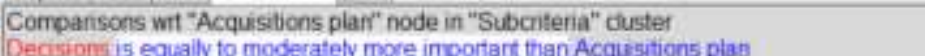 & \multicolumn{2}{|c|}{ 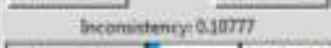 } \\
\hline Acquistions:- & 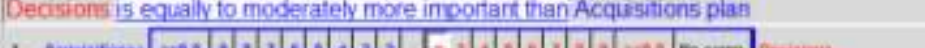 & \begin{tabular}{|l|l} 
Acqusititi- \\
\end{tabular} & 0.12103 \\
\hline Cluster: Subciteria & 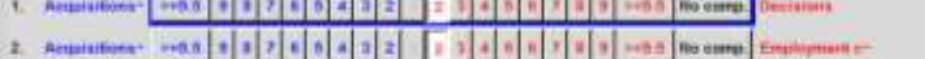 & \begin{tabular}{|l} 
Decisions \\
Employmen-
\end{tabular} & $\frac{0.48143}{0.14816}$ \\
\hline Choose Cluster $\leq y$ & 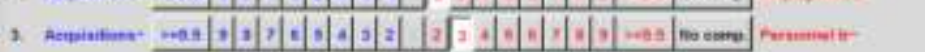 & Personnet- & 0.24936 \\
\hline Subotere & 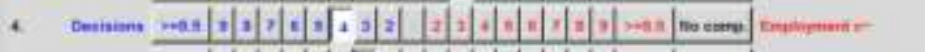 & & \\
\hline & 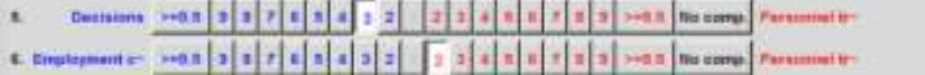 & & \\
\hline
\end{tabular}


b) "Decisions"

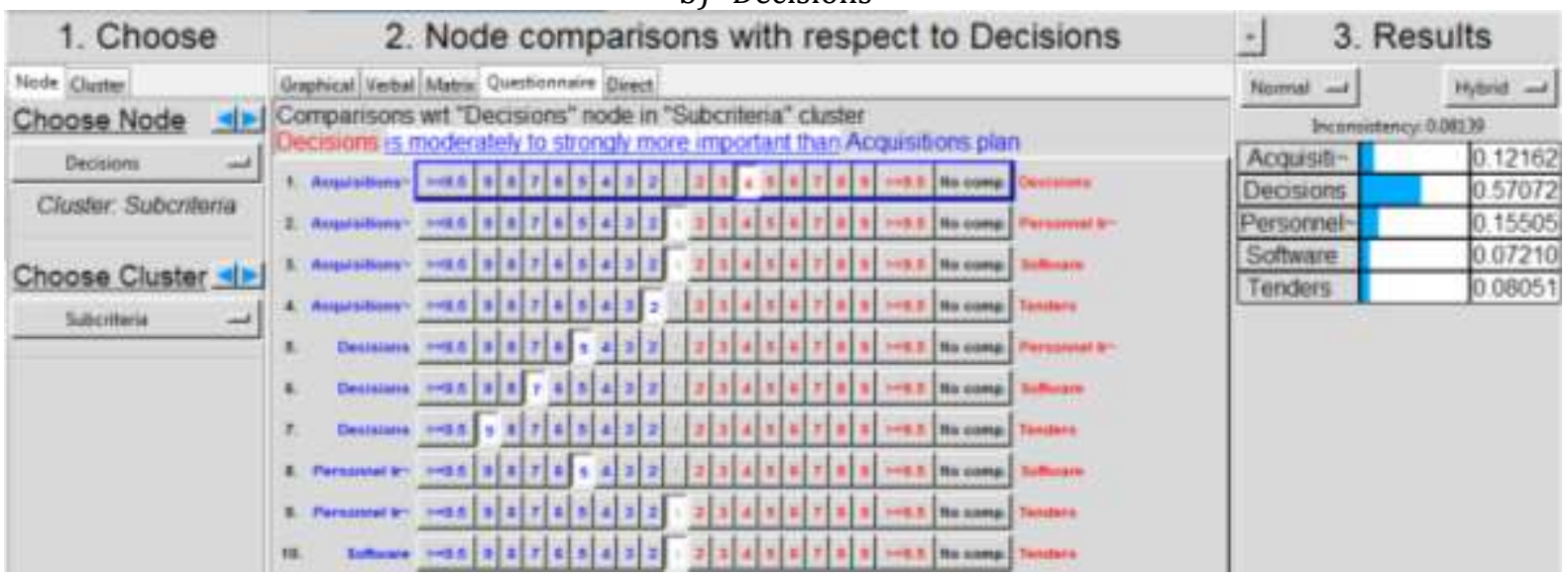

Figure 8. The inner dependencies of the subcriteria. (continued)

c) "Employment criteria"

\section{$\begin{array}{ll}\text { 1. Choose } & \text { 2. Node comparisons with respect to Employment criteria }\end{array}$}

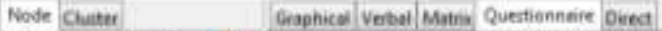

Choose Node $4=0$ Companisons wit "Employment criteria" node in "Subciteria" ciuster

Deosions is extremely more important than Employment criteria

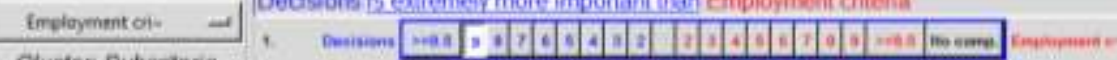

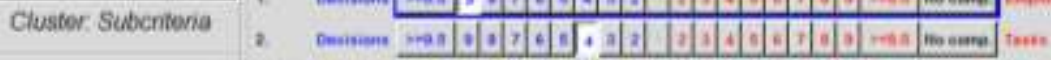

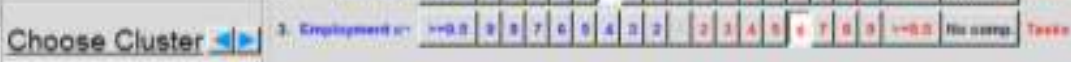

Subenteris -1

d) "Personnel training"

\begin{tabular}{|c|c|c|c|}
\hline 1. Choose & 2. Node comparisons with respect to Personnel training & \multicolumn{2}{|c|}{ 3. Results } \\
\hline Node Cluster & 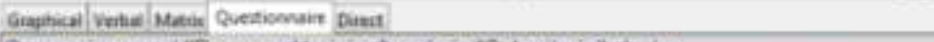 & Nemen -1 & H,tind - \\
\hline Choose Node $\leq \mid \mathrm{l}$ & 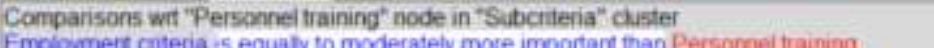 & \multicolumn{2}{|c|}{ heonidengososono } \\
\hline Fensoneition- & Q & Employmen- & 013401 \\
\hline Cluster Subcriteria & $2 \operatorname{tm}=5$ & \begin{tabular}{|c|} 
Personnel- \\
Tasis \\
\end{tabular} & $\frac{0.09291}{0.77308}$ \\
\hline Choose Cluster $\frac{\Delta}{\text { Subunen }}$ & 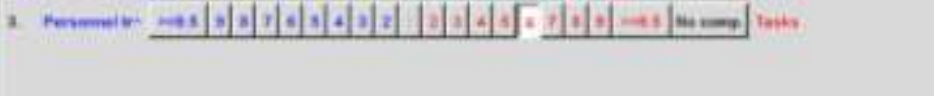 & & \\
\hline
\end{tabular}

e) "Software"

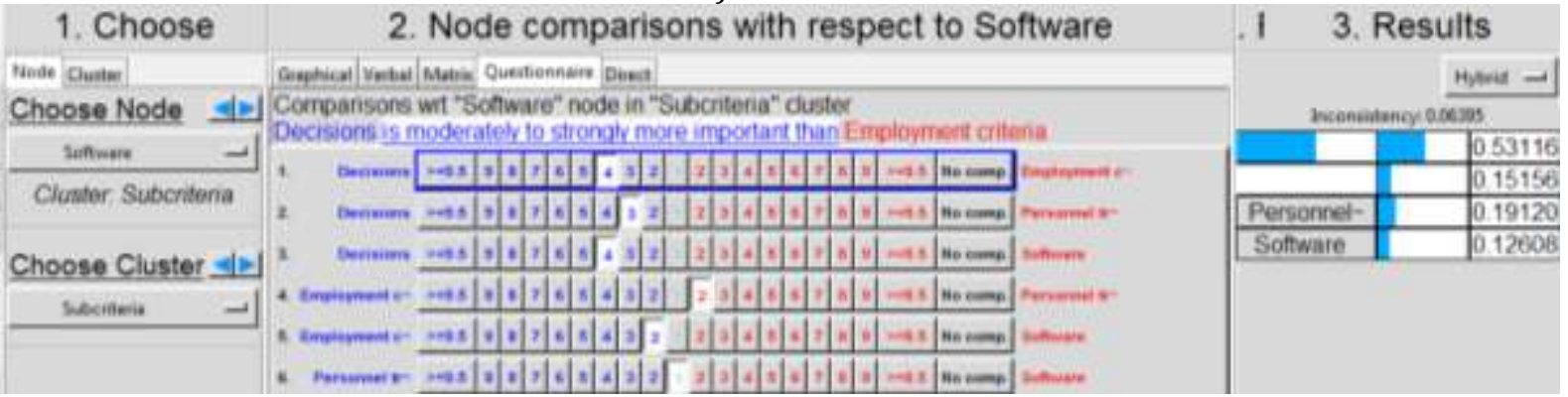

f) "Software usage"

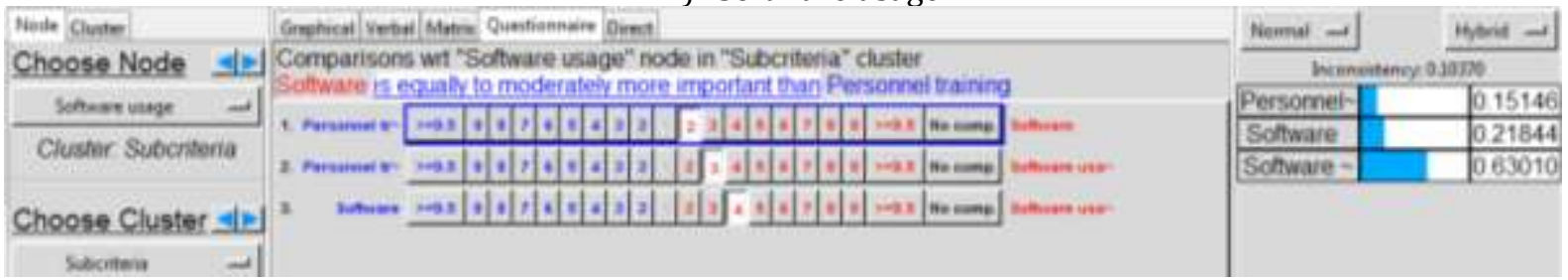


g) "Tasks"

\begin{tabular}{|c|c|c|c|}
\hline 1. Choose & 2. Node comparisons with respect to Tasks & \multicolumn{2}{|c|}{ 3. Results } \\
\hline Node Chuter & Gaphical Vebal Mattix Questionnaire Dient & Normal -1 & Hend -1 \\
\hline Choose Node 1 |l & Cormparisons wit "Tasks" node in "Subcritena" cluster & \multicolumn{2}{|c|}{ Inconintency 0.02795} \\
\hline-1 & 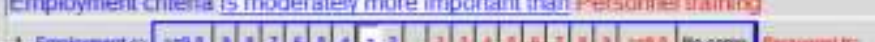 & Employmenc & 0.17818 \\
\hline Cluster Subcritena & 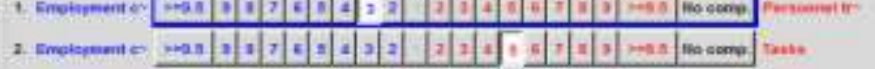 & \begin{tabular}{|c|} 
Personnel- \\
Task5 \\
\end{tabular} & $\frac{0.07042}{0.75140}$ \\
\hline Choose Cluster $\frac{\Delta}{\text { Subutaris }}$ & 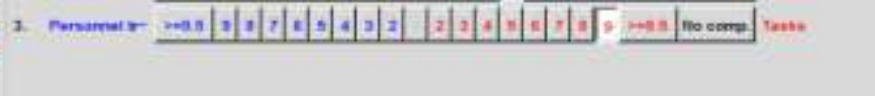 & & \\
\hline
\end{tabular}

h) "Tenders"

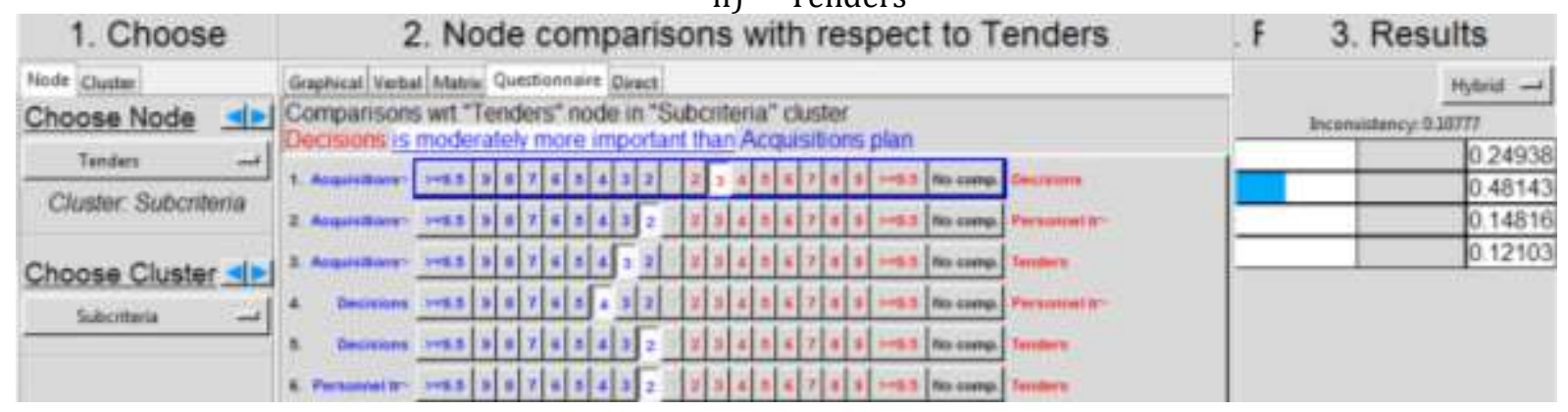

\section{Step 5. The inner dependencies of the methods}

We compare the measures and construct their inner dependencies taking into account the Tables $28 \div 34$ (Istrate et al, 2018) and Figure 4. Figure 9 presents these inner dependencies for the methods: "Competence" (Figure 9a), "Economy" (Figure 9b), "Education" (Figure 9c), "Efficiency" (Figure 9d), "Evaluation" (Figure 9e), "Finance" (Figure 9f) and "Training" (Figure 9g).

Figure 9. The inner dependencies of the methods

a) "Competence"

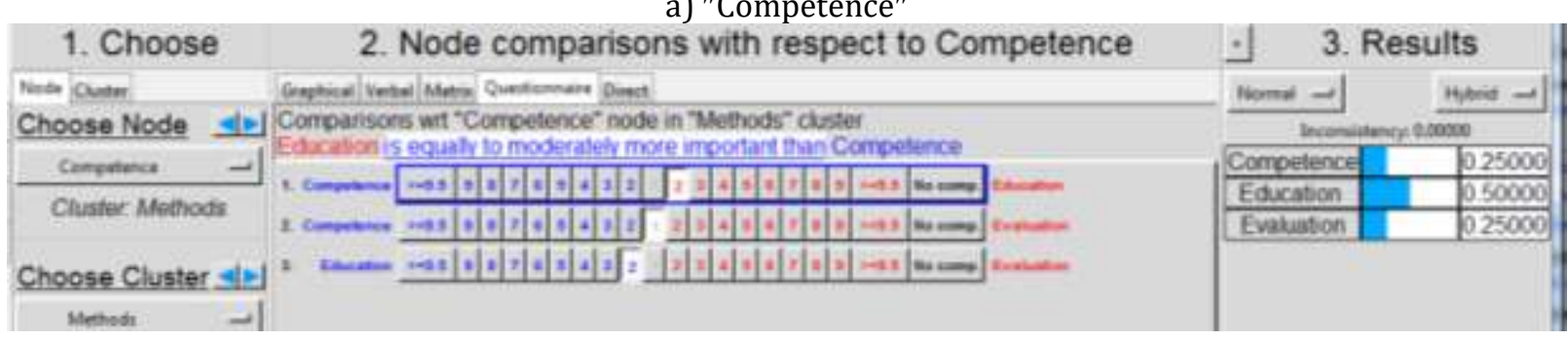

a) "Economy"

\begin{tabular}{|c|c|c|c|}
\hline 1. Choose & 2. Node comparisons with respect to Economy & \multicolumn{2}{|c|}{ 3. Results } \\
\hline Hedv Chiter: & 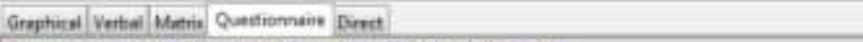 & Normai -1 & itybuid - 1 \\
\hline Choose Node $\leq \mid>1$ & Comparisons wit "Economy" node in "Method"s" custer & \multicolumn{2}{|c|}{ Incentiatancy 0.10035} \\
\hline fremiany & 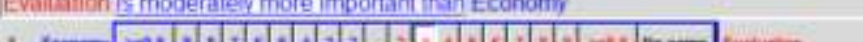 & Econsatiy & 0.07037 \\
\hline Cluster Methods & 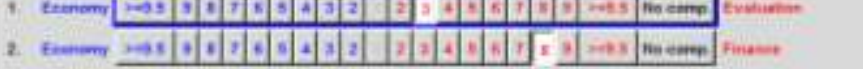 & \begin{tabular}{|l|} 
Evaluation \\
Finance \\
\end{tabular} & $\frac{0.15304}{0.77659}$ \\
\hline noose Cluster $\leq \mid y$ & 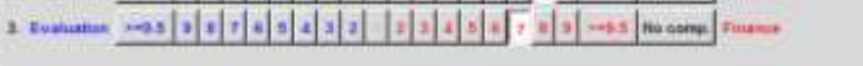 & & \\
\hline Methodo & & & \\
\hline
\end{tabular}

b) "Education"

\begin{tabular}{|c|c|c|c|}
\hline 1. Choose & 2. Node comparisons with respect to Education & \multicolumn{2}{|c|}{ 3. Results } \\
\hline Noste anes & 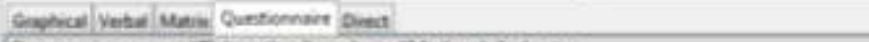 & Norind -1 & H,and -1 \\
\hline Choose Node $\leq t \mid$ & Companisons wit "Education' node in "Heehods" duster & \multicolumn{2}{|c|}{ 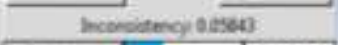 } \\
\hline Bentere & 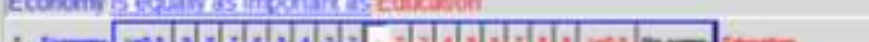 & Economy & 0.33590 \\
\hline Chuster Methods & 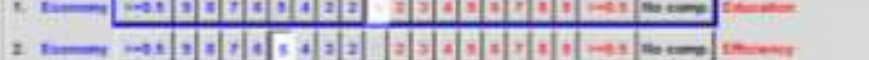 & \begin{tabular}{|l|l|} 
Edication \\
Effoency
\end{tabular} & $\frac{0.43350}{0.05529}$ \\
\hline noose Cluster sto & 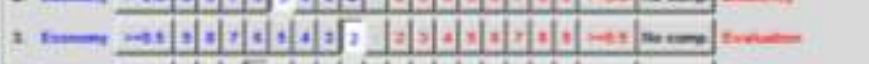 & Eviluation & 217516 \\
\hline Mond -1 & 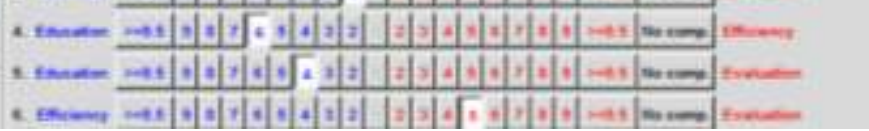 & & \\
\hline
\end{tabular}


c) "Efficiency"

\begin{tabular}{|c|c|c|c|}
\hline 1. Choose & 2. Node comparisons with respect to Efficiency & \multicolumn{2}{|c|}{ 3. Results } \\
\hline Noth oute & 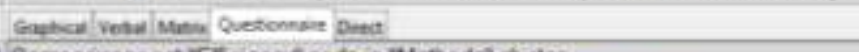 & $n-1$ & Heted -1 \\
\hline Choese Node $\leq 4$ & Compansons int Ethoenor node in Tlethods dustes & \multicolumn{2}{|c|}{ Monitumer taven } \\
\hline 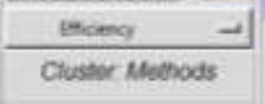 & 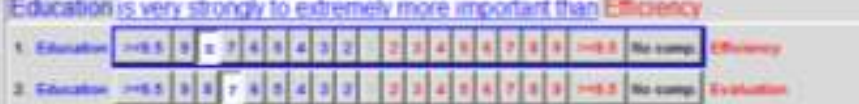 & \begin{tabular}{|l|} 
Eouchition \\
Efcieng \\
Evaliation
\end{tabular} & $\begin{array}{l}077059 \\
0.07037 \\
015304\end{array}$ \\
\hline Choose Cluster $\leq t y$ & 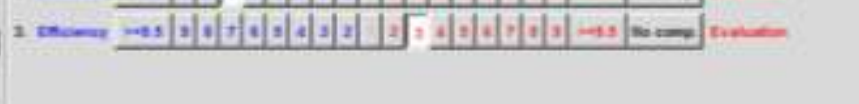 & & \\
\hline
\end{tabular}

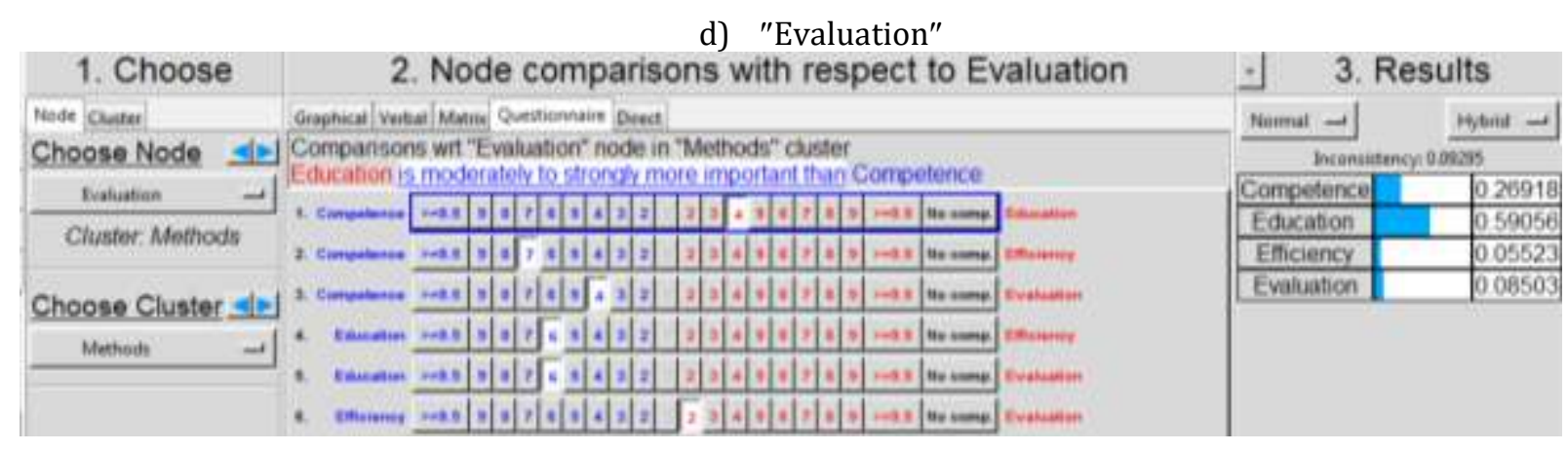

Figure 9. The inner dependencies of the methods. (continued)

e) "Finance"

\begin{tabular}{|c|c|c|c|}
\hline 1. Choose & 2. Node comparisons with respect to Finance & \multicolumn{2}{|c|}{ 3. Results } \\
\hline Mose Oester & 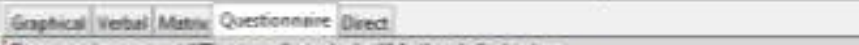 & Nomed -1 & Higned - \\
\hline Choose Node $\leq \mid y$ & Comparisons ant "Finance" node in "Methods" dister & \multicolumn{2}{|c|}{ 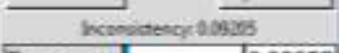 } \\
\hline Fance & 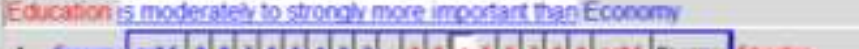 & Economy & 0.03522 \\
\hline Cluster Mlethods & 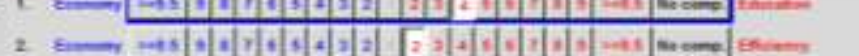 & \begin{tabular}{|l|l|l} 
Educabon \\
Emoenof
\end{tabular} & $\mid 017842$ \\
\hline Choose Cluster $\leq \mid y$ & 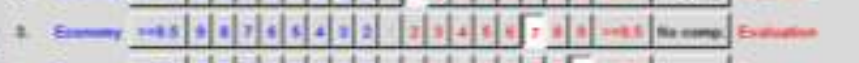 & 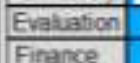 & \begin{tabular}{|c|c|}
017467 \\
0.56572
\end{tabular} \\
\hline nent - & 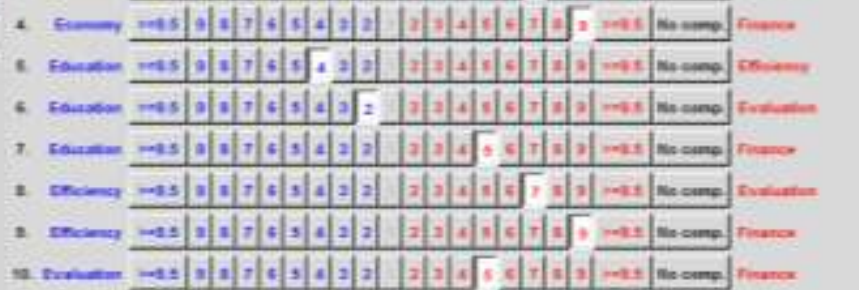 & & \\
\hline
\end{tabular}

f) "Training"

\begin{tabular}{|c|c|c|c|}
\hline 1. Choose & 2. Node comparisons with respect to Training & - & ults \\
\hline Hode Conter & Graphicat Vetbail Merim Gentionnain Dinet & Nemal -1 & motend -1 \\
\hline Choose Node $\leq|r|$ & $\begin{array}{l}\text { Comparisons wrt "Training" node in "Methods" cluster } \\
\text { Finance is strongly to very strongly moxe imsortart than Trining }\end{array}$ & \multicolumn{2}{|c|}{ Intentitency; 0.00000} \\
\hline Theining & 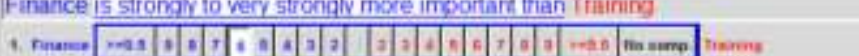 & Finance & 085714 \\
\hline Cluster Methods & & Training & 10.14286 \\
\hline$\frac{\text { Choose Cluster } \leq|l|}{\text { Methode }}$ & & & \\
\hline
\end{tabular}

\section{Step 6. The methods priorities}

Using the "Computations" $\rightarrow$ "Priorities " sequence, the software presents us the priorities of the methods considered in the analysis of the company performance. Figure 10 presents these priorities. 
Figure 10. The methods priorities.

\begin{tabular}{|c|c|c|c|}
\hline No Icon & Competence & 0.05185 & 0.051851 \\
\hline No Icon & Economy & 0.13254 & 0.132543 \\
\hline No Icon & Education & 0.33901 & 0.339008 \\
\hline No Icon & Efficiency & 0.04249 & 0.042489 \\
\hline No Icon & Evaluation & 0.15558 & 0.155581 \\
\hline No Icon & Finance & 0.26457 & 0.264569 \\
\hline No Icon & Training & 0.01396 & 0.013960 \\
\hline
\end{tabular}

\section{Results and discussions}

The priorities of the measures that a company should take in order to improve its activity show that the "Education" occupies the first place (a weight value of 0.339 ) followed immediately by the "Finance" (a weight value of 0.2645 ). The third measure that the analyzed company should take into consideration is "Evaluation" (0.1555) followed immediately by "Economy" (0.339). We find here the same conclusions that were obtained previously using the classical method of solving this AHP/ANP problem (see Istrate et al., 2018).

\section{Conclusions}

The modern technology represents an achievement that changes the way in which the new generations of students, researchers, et al. are defining their working environment. The well established numerical, analytical and computational methods are presented to the user in a manner that becomes friendlier, easier to understand and to use. The AHP/ANP methods are not an exception. A great number of software programs are presenting these methods in an actual, modern way and the SuperDecision software is one of them.

This paper presents the general problem of a company activity improvement. Considering general factors, using both the AHP and the ANP methods and the new technology available, this work leads the reader through the process of translation of the intuitive arguments into the new environment in order to establish the priorities that should lead the analysis team.

The company considered here is an example that can be modified and adapted for other particular cases that the reader is interested of. This paper, also, constitutes an example of the way in which the modern technology can improve the analysis activity in a company.

\section{References}

1. Akyildiz, B., Kadaifci, C. and Topcu, I. (2015), "A decision framework proposal for customer order prioritization: a case study for a structural steel company", Int. J. Production Economics, Volume 169, pp. 21-30.

2. Alhuraish, I., Robledo, C. and Kobi, A. (2016), "Assessment of lean manufacturing and six sigma operation with decision making based on the analytic hierarchy process", IFAC-PapersOnLine, Volume 49-12, pp. 059-064.

3. Aragonés-Beltrán, P., Chaparro-González, F., Pastor-Ferrando, J.-P., Pla-Rubio, A. (2014), "An AHP (Analytic Hierarchy Process)/ANP (Analytic Network Process)-based multi-criteria decision approach for the selection of solar-thermal power plant investment projects", Energy, Volume 66, pp. 222-238.

4. Aragoné-Beltrán, P., Poveda-Bautista, R. and Jimérez-Sáez, F. (2017), “An in-depth analysis of a TTO's objective alignment within the university strategy: an ANP-based approach", Journal of Engineering and Technology Management, Volume 44, pp. 19-43.

5. Atmaca, E. and Basar, H. B. (2012), "Evaluation of power plants in Turkey using Analytic Network Process (ANP)", Energy, Volume 44, pp. 555-563.

6. Burnaz, S. and Topcu, Y. I. (2011), "A decision support on planning retail tenant mix in shopping malls", Proceeding Social and Behavioral Sciences, Volume 24, pp. 314-324.

7. Cannemi, M., García-Melón, M., Aragonés-Beltrán, P. and Gómez-Navarro, T. 2014), "Modeling decision making as a support tool for policy making on renewable energy development", Energy Policy, Volume 67, pp. 127-137.

8. De Ambriggi, M. and Trucco, P. (2011), "Modelling and assessment of dependent performance shaping factors through Analytic Network Process", Reliability Engineering and System Safety, Volume 96, pp. 849 - 860.

9. Gibney, R. and Shang, J. (2007), "Decision making in academia: a case of the dean selection process", Mathematical and Computer Modelling, Volume 46, pp. 1030-1040.

10. Hallikainen, P, Kivijärvi, H. and Tuominen, M. (2009), "Supporting the module sequencing decision in the ERP implementation process An application of the ANP method", Int. J. Production Economics, Volume 119, pp. 259-270.

11. Hasan, M., A; Sarkis, J. and Shankar, R. (2012), "Agility and production flow layouts: an analytic decision analysis", Computer \& Industrial Engineering, Volume 62, pp. 898-907.

12. Istrate, S., Nestian, V. and Neagu, M. (2018), "A company improvement analysis using the AHP and the ANP methods", The Annals of "Dunarea de Jos" of Galati, Fascicle I. Economics and Applied Informatics, (submitted for publication)

13. Ivanovíc, I., Grujičič, D., Macura, D., Jović, J. and Bojović, N. (2013), "One approach for road transport project selection", Transport Policy, Volume 25, pp. 22-29.

14. Keramati, A. and Salehi, M. (2013), “Website success comparison in the context of e-recruitment: An analytic network process (ANP) approach", Applied Soft Computing, Volume 13, pp. 173-180.

15. Lin, M.-C., Wang, C.-C., Chen, M.-S., Chang, C. A. (2008), "Using AHP and TOPSIS approaches in customer-driven product design process", Computers in Industry, Volume 59, pp. 17-31. 
16. Milani, A.S., Shanian, A., Lynam, C. and Scarinci, T. (2013), "An application of the analytic network process in multiple criteria material selection", Materials and Design, Volume 44, pp. 622-632.

17. Mu, E. and Carroll, J (2016), "Development of a fraud risk decision model for prioritizing fraud risk cases in manufacturing firms", Int. J. Production Economics, Volume 173, pp. 30-42.

18. Neagu, M. (2016), "Concepts, methods and applications in Concurrent Engineering", Iaşi, România: Tehnopress.

19. Neagu, M. (2017), “Concurrent Engineering. Laboratories", Iași, România: Tehnopress.

20. Önüt, S., Tuzkaya, U. R. and Saadet, N. (2008), "Multiple criteria evaluation of current energy resources for Turkish manufacturing industry", Energy Conversion and Manufacturing, Volume 49, pp. 1480-1492.

21. Xu, P. and Chan, E. H. W. (2013), "ANP model for sustainable building energy efficiency retrofit (BEER) using energy performance contracting (EPC) for hotel buildings in China", Habitat International, Volume 37, pp. 104-112. 